\title{
Modification of Local Urban Aerosol Properties by Long-Range Transport of Biomass Burning Aerosol
}

\author{
Iwona S. Stachlewska 1,* (D), Mateusz Samson ${ }^{1,2}$, Olga Zawadzka ${ }^{1}$ (D), Kamila M. Harenda ${ }^{2}$, \\ Lucja Janicka ${ }^{1}$, Patryk Poczta ${ }^{2,3}$, Dominika Szczepanik ${ }^{1}$, Birgit Heese ${ }^{4}$, Dongxiang Wang ${ }^{1}$, \\ Karolina Borek ${ }^{1}$, Eleni Tetoni ${ }^{1,5,6}$, Emmanouil Proestakis ${ }^{5}$, Nikolaos Siomos ${ }^{7}$, Anca Nemuc ${ }^{8}$, \\ Bogdan H. Chojnicki ${ }^{2}$, Krzysztof M. Markowicz ${ }^{1}$, Aleksander Pietruczuk ${ }^{9}$, Artur Szkop ${ }^{9}$, \\ Dietrich Althausen ${ }^{4}$, Kerstin Stebel ${ }^{10}$ iD, Dirk Schuettemeyer ${ }^{11}$ and Claus Zehner ${ }^{12}$ \\ 1 Institute of Geophysics, Faculty of Physics, University of Warsaw, 02-093 Warsaw, Poland; \\ mateusz.samson@up.poznan.pl (M.S.); olga.zawadzka@fuw.edu.pl (O.Z.); lucja.janicka@fuw.edu.pl (L.J.); \\ dominika.szczepanik@fuw.edu.pl (D.S.); dongxiang.wang@fuw.edu.pl (D.W.); \\ karolina.borek@fuw.edu.pl (K.B.); eleni.tetoni@noa.gr (E.T.); krzysztof.markowicz@fuw.edu.pl (K.M.M.) \\ Department of Meteorology, Faculty of Environmental Engineering and Spatial Management, Poznan \\ University of Life Sciences, 60-649 Poznan, Poland; kamila.harenda@up.poznan.pl (K.M.H.); \\ patryk.poczta@up.poznan.pl (P.P.); bogdan.chojnicki@up.poznan.pl (B.H.C.) \\ 3 Department of Grassland and Natural Landscape Sciences, Faculty of Agronomy and Bioengineering, \\ Poznan University of Life Sciences, 60-632 Poznan, Poland \\ 4 Leibniz Institute for Tropospheric Research, 04318 Leipzig, Germany; birgit.heese@tropos.de (B.H.); \\ dietrich.althausen@tropos.de (D.A.) \\ 5 Institute for Astronomy, Astrophysics, Space Applications and Remote Sensing, National Observatory of \\ Athens, 15236 Athens, Greece; proestakis@noa.gr \\ 6 Division of Environmental Physics and Meteorology, Faculty of Physics, National and Kapodistrian \\ University of Athens, 15784 Athens, Greece \\ 7 Laboratory of Atmospheric Physics, Physics Department, Aristotle University of Thessaloniki, 54124 \\ Thessaloniki, Greece; nsiomos@physics.auth.gr \\ 8 National Institute for Research and Development in Optoelectronics, 077125 Magurele, Romania; \\ anca@inoe.ro \\ 9 Institute of Geophysics, Polish Academy of Sciences, 01-452 Warsaw, Poland; alek@igf.edu.pl (A.P.); \\ aszkop@igf.edu.pl (A.S.) \\ 10 Atmosphere and Climate Department, Norwegian Institute for Air Research, 2027 Kjeller, Norway; \\ Kerstin.Stebel@nilu.no \\ 11 European Space Research and Technology Centre, European Space Agency, 2201 Noordwijk, The \\ Netherlands; Dirk.Schuettemeyer@esa.int \\ 12 European Space Research Institute, European Space Agency, 00044 Frascati, Italy; Claus.Zehner@esa.int \\ * Correspondence: iwona.stachlewska@fuw.edu.pl
}

Received: 31 December 2017; Accepted: 2 March 2018; Published: 7 March 2018

\begin{abstract}
During August 2016, a quasi-stationary high-pressure system spreading over Central and North-Eastern Europe, caused weather conditions that allowed for 24/7 observations of aerosol optical properties by using a complex multi-wavelength PollyXT lidar system with Raman, polarization and water vapour capabilities, based at the European Aerosol Research Lidar Network (EARLINET network) urban site in Warsaw, Poland. During 24-30 August 2016, the lidar-derived products (boundary layer height, aerosol optical depth, Ångström exponent, lidar ratio, depolarization ratio) were analysed in terms of air mass transport (HYSPLIT model), aerosol load (CAMS data) and type (NAAPS model) and confronted with active and passive remote sensing at the ground level (PolandAOD, AERONET, WIOS-AQ networks) and aboard satellites (SEVIRI, MODIS, CATS sensors). Optical properties for less than a day-old fresh biomass burning aerosol, advected into Warsaw's boundary layer from over Ukraine, were compared with the properties of long-range transported 3-5 day-old aged biomass burning aerosol detected in the free troposphere over Warsaw. Analyses of temporal changes of aerosol properties within the
\end{abstract}


boundary layer, revealed an increase of aerosol optical depth and Ångström exponent accompanied by an increase of surface $\mathrm{PM}_{10}$ and $\mathrm{PM}_{2.5}$. Intrusions of advected biomass burning particles into the urban boundary layer seem to affect not only the optical properties observed but also the top height of the boundary layer, by moderating its increase.

Keywords: boundary layer; aerosol properties; Raman lidar; SEVIRI; $\mathrm{PM}_{2.5}$; $\mathrm{PM}_{10}$; aerosol optical depth; biomass burning; anthropogenic pollution

\section{Introduction}

The fair-weather, being a prerequisite for remote sensing observations of aerosol optical properties, leads to a clear-sky observational bias, which is obvious in the measurements of the EARLINET [1] and AERONET [2] networks. Over Europe, the cloudless conditions are often related to persistent for several days, quasi-stationary high pressure systems covering large geographical areas of the continent. Such weather dynamics provide an excellent test-bed for performing quasi-continuous ground-based passive and/or active remote sensing of optical properties of aerosols suspended in the air above the measurement site, whether on a local [3-5] or regional scale [6,7]. Such conditions also give great opportunities for retrieval of aerosol optical properties from satellite remote sensing (MODIS, SEVIRI), which are obviously hindered by cloud occurrence [8,9]. On the other hand, before/after anticyclones, cloud systems may form relatively slowly, which allows for remote sensing studies of aerosol-tocloud transitions [10].

Depending on their type, atmospheric aerosols can cause a cooling or a warming at the surface or at the height of aerosol layer, whereby the aerosol radiative forcing effect is also a function of the surface albedo. The altitude of the boundary layer top, as well as vertical change of wind speed and temperature significantly impact vertical distribution of the aerosol optical and microphysical properties in the lower troposphere [11-14]. They are found to also have an effect on concentrations of air pollutants, specifically over large cities $[5,15,16]$. Turbulence diffusion and boundary layer height are important meteorological factors affecting air pollution episodes, which is evident from their negative correlations with near-surface particulate matter of a size of less than $2.5 \mu \mathrm{m}\left(\mathrm{PM}_{2.5}\right)$ [17]. On the other hand, anti-correlations of boundary layer height and surface $\mathrm{PM}_{2.5}$ with the Ångström exponent are discernible for highly polluted urban atmosphere [5].

Heat trapped within the boundary layer by stationary anticyclones can trigger heat wave conditions [18-21] that can favour development of intense fires, locally causing an increase of the aerosol amount within the boundary layer [3,4,22,23]. Often such fire-induced aerosols are observed at long distances from the source $[13,24,25]$ and/or spread over large areas $[7,26]$. Depending on specific weather circulation, the fire-induced aerosol transport can be heat wave driven $[3,5]$. Both local and long-range transported wildfire aerosols can have a large impact on typically observed aerosol properties and therefore their occurrence over particular areas leads to large changes of radiative fluxes [22,27,28]. The effects of wildfire aerosols on the PM air quality are expected to be significant [29]. Based on available satellite data, distinguishing between combustion types and their separation from biomass burning is possible [30]. Interaction between high levels of air pollution and high temperatures $\left(\geq 30{ }^{\circ} \mathrm{C}\right.$ ) are reported as statistically significant for sulphur dioxide (due to primary combustion pollution) and as a suggestive for black [31]. In such conditions, inhabitants of urban areas can experience significant health problems [32-35].

In general, quasi-stationary weather conditions can contribute to the formation of multiple aerosol layers in the atmosphere. These can be attributed to air masses of either local or advection driven origin. For the latter case, one may consider long-range transported pollution such as arctic haze [36], mineral dust intrusions [16,35,37,38], volcanic aerosols [39-41] and biomass burning [7,25,27,42]. Aerosol properties within the multi-layered atmosphere can be observed by means of height-resolved 
ground-based or satellite lidar observations (e.g., EARLINET, PollyNET, CATS); although for the majority of world-wide spread ground-based lidars, the spectral measurements are not available due to their complexity, high development cost and necessity to employ skilled personnel for lidar operation and data retrieval. On the contrary, spectrally resolved passive remote sensors on the ground level or in space, provide information solely on columnar aerosol properties (e.g., AERONET, SEVIRI, MODIS). Therefore, studies combining active and passive, ground-based and satellite remote sensing with information from in-situ sensors (e.g., particulate matter) and atmospheric transport models (e.g., HYSPLIT, NAAPS, CAMS), as well as complementing such studies with airborne remote sensing [43] and/or airborne in-situ sampling [44], are of continuously increasing interest. Due to complexities of atmospheric processes and their interplay, the implications for air-quality or health risk cannot be assessed without the combination of a multi-instrumental and multi-spatial approach.

The broader goal of the current paper is to discuss a variety of remote sensing observations conducted at the end of August 2016, when a large anticyclonic, quasi-stationary high pressure system that spread over North Eastern Europe, brought air from over the Iberian Peninsula, via Scandinavia and Eastern Europe to Central Europe. The specific goal is to analyse the effects of intrusion of long-range transported aerosols into the urban boundary layer.

The paper is organized as follows. In Section 2, the instrumentation employed for this study is introduced. In Section 3, the data evaluation schemes are described. In Section 4, the general weather situation and air mass transport is given. Section 5 is dedicated to results, including analyses of the optical properties of the atmosphere, derived by means of the active and passive ground based and satellite sensors. In Section 6, the results are discussed and interpreted. In Section 7, the work is concluded.

\section{Instruments}

\subsection{Active Remote Sensors}

PollyXT Raman Polarization Lidar. Since July 2013, lidar remote sensing observations have been conducted at the Radiative Transfer Laboratory (RT-Lab) of the Institute of Geophysics, at the Faculty of Physics, of the University of Warsaw, Poland. The RT-Lab located in the city-centre of Warsaw $\left(52.21^{\circ} \mathrm{N}, 20.98^{\circ} \mathrm{E}, 112 \mathrm{~m}\right.$ a.s.l.) provides high quality measurements as a part of the Polish aerosol research network (PolandAOD, www.polandaod.pl, supplement material in [26]). The station represents the only Polish Raman lidar site within the European Aerosol Research Lidar Network (EARLINET, www.earlinet.org, [1]), contributing to the measurements of the worldwide Polly.NET lidar network (www.polly.tropos.de, [6]). In this study, we employed the 12-channel NeXT generation PollyXT lidar [45] capable of quasi-automated $24 / 7$ operation. The lidar uses a single Nd-YAG laser as a light source (laser pulses of 180/110/60 mJ at 1064/532/355 nm emitted with $20 \mathrm{~Hz}$ frequency) and two telescopes with two independent optoelectronic wavelength-separation units designed for the far and near-range detection. Three laser beams are sent simultaneously and co-axially into the atmosphere (beams expanded to a $45 \mathrm{~mm}$ diameter to decrease beam divergence to $0.2 \mathrm{mrad}$ ). The backward scattered laser light is collected onto two Newtonian-type telescopes, these being, a large far-range (300 mm primary mirror, $0.9 \mathrm{~mm}$ pinhole, $1 \mathrm{mrad}$ field of view) and a small near-range (50 mm primary mirror, $0.4 \mathrm{~mm}$ fibre-core, $2 \mathrm{mrad}$ field of view). The detection is done separately for the far (8-channels) and near range (4-channels), together being able to provide a so-called $3 \beta+2 \alpha+2 \delta+w v$ data set with exceptional range coverage. The far-range optical wavelength separator is used to determine the elastic scattering at 1064, 532 and $355 \mathrm{~nm}$, the elastic cross-polarized scattering at 532 and $355 \mathrm{~nm}$, the vibrational Raman scattering for N2 at 607 and $387 \mathrm{~nm}$ and for $\mathrm{H} 2 \mathrm{O}$ at $407 \mathrm{~nm}$. The Near Range Aerosol Lidar (NARLa) measures backward elastic scattering at 532 and $355 \mathrm{~nm}$ and N2 Raman scattering at 607 and $387 \mathrm{~nm}$. The NARLa is designed to significantly enhance the lowermost range of lidar observations; therefore, the design allows its easy dismounting from the main PollyXT 
lidar setup and to use it independently with other lidars. For all channels, solely photon-counting detection is performed with Hamamatsu H10721P-110 modules (dead time of $\sim 2 \mathrm{~ns}$ ), except for the $1064 \mathrm{~nm}$ wavelength where extra-cooled Hamamatsu R3236 is used. The signals are acquired with $600 \mathrm{MHz}$ photon counters (providing $7.5 \mathrm{~m}$ height resolution) and recorded up to $48 \mathrm{~km}$ with 250 range bins pre-trigger length. For all detection channels, narrow-bandwidth interference filters of $1 \mathrm{~nm}$ or $0.3 \mathrm{~nm}$ (N2 Raman channels) are used to achieve at least 8 times suppression. The incomplete geometrical overlap range between the emitted laser beam and the full field of view of the lidar telescope, affects measured signals. The difference of the overlap range at each channel is regarded as negligible ( $\pm 15 \mathrm{~m}$ for non-smoothed profiles at both telescopes). Signals in the range below $400 \mathrm{~m} / 120 \mathrm{~m}$ altitude (in far/near range) are rejected from further evaluation as overlap-range is affected.

CHM15k Ceilometer. Apart from the lidar measurements in Warsaw, the aerosol vertical structures were measured using ceilometers (CHM15k, JenOptik-Lufft) at two Polish Aerosol Research Network (PolandAOD) sites in Strzyzow (SolarAOT Observatory) and Raciborz (Polish Academy of Sciences Observatory). The CHM15k instrument operates at single-wavelength (1064 nm) laser radiation with 7-9 $\mu \mathrm{J}$ pulse energy, $5-7 \mathrm{kHz}$ pulse repetition rate and 1-5 ns pulse duration. The laser beam divergence is small ( $<0.3 \mathrm{mrad}$ ) for the output beam diameter expanded to $90 \mathrm{~mm}$. Elastic backscattering signal is detected in a photon counting mode. Typical signal averaging is set to $15 \mathrm{~min}$ for height resolution of $30 \mathrm{~m}$ (Strzyzow)/15 m (Raciborz). The receiver field of view is of $0.45 \mathrm{mrad}$. The overlap of the receiver and emitter geometry is completed at about $500 \mathrm{~m}$. The instrument targets the measurements of the aerosols, cloud droplets and ice crystals. The measured parameters are among others: raw backscattering signals, cloud base height up to 9 layers (including penetration depth), sky condition and cloud amount.

CATS System. Satellite-based active remote sensing performed with NASA's Cloud Aerosol Transport System (CATS) is also used. The CATS, installed on-board the International Space Station (ISS) at the Japanese Experimental Module-Exposed Facility (JEM-EF), provided near real-time, continuous and height-resolved information on the vertical structure of aerosols and clouds along the ISS orbit track for the period between 10 February 2015 and 29 September 2017 [46]. Since CATS utilizes the ISS as a platform, the remote sensors were bound to orbit the Earth from an altitude of approximately $405 \mathrm{~km}$ and 51-degree inclination. During the operation period of CATS, unexpected issues limited scope of planned measurements [47] and the system provided semi-continuous retrievals of backscattering, extinction and polarization properties of aerosols and clouds at $1064 \mathrm{~nm}$, aerosol type classification, aerosol layer height, thickness and optical depth (https:/ / cats.gsfc.nasa.gov).

\subsection{Passive Remote Sensors}

CE318 Sunphotometer. Automatic sun/sky scanning photometers (CE318; CIMEL Electronique) were used to measure direct and diffuse solar irradiance and sky radiance at the Earth's surface at nine wavelengths in a spectral range from $340 \mathrm{~nm}$ to $1640 \mathrm{~nm}$. The $936 \mathrm{~nm}$ channel was used to estimate the total water vapour column and the remaining channels for retrieval of aerosol optical depth (AOD). Measurements were performed at three PolandAOD network sites in Strzyzow (SolarAOT Observatory), Rzecin (PolWET station of Poznan University of Life Sciences) and Raciborz (Polish Academy of Sciences Observatory). The raw measurements are uploaded and processed by the Aerosol Robotic NETwork (AERONET, [2]) to derive among others spectrally dependent AOD with uncertainty at the level of \pm 0.01 .

MFR-7 Radiometer. Multi-Filter Rotating Shadowband Radiometers (MFR-7; Yankee Environmental Systems) was used for continuous measurements of spectrally dependent AOD at the PolandAOD network measurement site in Warsaw (RT-Lab of University of Warsaw). The instrument operates at six narrow-band channels $(415,500,610,675,870$ and $940 \mathrm{~nm})$ and one broadband channel to measure direct, diffuse and total solar radiation. Regular in-situ calibration is applied using the classic Langley approach. Due to significant degradation of diffuser and filter optical properties that 
influence measurement sensitivity, the uncertainty of the retrieved AOD is higher than that of the CE318 instruments, being at the level of \pm 0.025 . Details on the instrument design and uncertainty analyses are reported in [48].

SEVIRI Sensor. The Meteosat Second Generation (MSG) geostationary satellite platform, developed by the European Organization for the Exploitation of Meteorological Satellites (EUMETSAT) in collaboration with the European Space Agency (ESA), is equipped with the Spinning Enhanced Visible and Infrared Imager (SEVIRI) instrument. Since 2004, SEVIRI provides observations of the Earth every $15 \mathrm{~min}$ [49]. The instrument collects nadir data in 12 spectral channels (in a range of $635 \mathrm{~nm}$ to $13.4 \mu \mathrm{m}$ ) with a spatial resolution for a sub-satellite point of $3 \mathrm{~km}$ for channels $1-11$ and $1 \mathrm{~km}$ for channel 12 (so-called High Resolution Visible channel). The SEVIRI data is stored automatically at the RT-Lab Data Server (EUMETSAT License No. 50001643). In the frame of this work, an in-house developed SEVIRI AOD retrieval algorithm was used for deriving the aerosol optical depth at $635 \mathrm{~nm}$ in near real-time over the territory of Poland [9].

MODIS Sensor. The moderate-resolution imaging spectroradiometer (MODIS) is a payload instrument launched into Earth's orbit by NASA in 1999, on board the Terra (EOS AM) Satellite and in 2002, on board the Aqua (EOS PM) satellite. Each instrument captures data in 36 spectral bands, ranging from $0.4 \mu \mathrm{m}$ to $14.4 \mu \mathrm{m}$ and at varying spatial resolutions ( 2 bands at $250 \mathrm{~m}, 5$ bands at $500 \mathrm{~m}$ and 29 bands at $1 \mathrm{~km}$ ). Together, the instruments image the entire Earth every 1 to 2 days. They are designed to provide measurements in large-scale global dynamics, including changes in Earth's cloud cover, radiation budget and processes occurring in the oceans, as well as on land and in the lower atmosphere. For the analyses of this paper, the AOD product derived at $500 \mathrm{~nm}$ was used, whereby the uncertainty of the retrieval was estimated depending on the value measured and calculated as $\pm(0.05+0.15 \cdot \mathrm{AOD})$.

\subsection{Surface PM Measurements and Metrological Data}

$\mathbf{P M}_{10}$ and $\mathbf{P M}_{2.5}$ counters. The surface daily and hourly mean particulate matter concentrations for particles with an aerodynamic diameter of less than 2.5 and $10 \mu \mathrm{m}$ (denoted $\mathrm{PM}_{2.5}$ and $\mathrm{PM}_{10}$, respectively) were obtained at one of the air-quality monitoring sites of the Warsaw Regional Inspectorate of Environmental Protection (WIOS), located in Warsaw-Ursynow (http://sojp.wios.warszawa.pl/raport-dobowy-i-roczny). The measurement uncertainty is below $30 \%$ for the hourly concentrations.

RS92 Radiosounding. The atmospheric pressure (p), temperature $(\mathrm{T})$ and relative humidity $(\mathrm{RH})$ profiles were obtained from the radiosounding (RS92 sonde, Vaisala) launched with $12 \mathrm{~h}$ frequency at two World Meteorological Organization sites located in Poland: the WMO 12374 station in Legionowo $\left(52.40^{\circ} \mathrm{N}, 20.96^{\circ} \mathrm{E}, 96 \mathrm{~m}\right.$ a.s.l.), being the closest radiosounding station to Warsaw ( $25 \mathrm{~km}$ to the North), as well as the WMO 12425 station in Wroclaw $\left(51.78^{\circ} \mathrm{N}, 16.88^{\circ} \mathrm{E}, 122 \mathrm{~m}\right.$ a.s.l.), being the closest radiosounding station to Raciborz (150 $\mathrm{km}$ to the North-West). The noon and midnight radiosounding profiles (launch at 11:15 UTC/23:15 UTC, duration of circa 1.5 h) at the two sites, were visualized and downloaded via the University of Wyoming Upper Air Data website (weather.uwyo.edu/upperair/ sounding.html).

WXT510 Weather Sensor. The temperature, pressure, relative humidity, wind speed and direction at the surface $\left(\mathrm{p}_{0}, \mathrm{~T}_{0}, \mathrm{RH}_{0}, \mathrm{~V}_{0}, \mathrm{Vdir}_{0}\right)$ were measured directly at the lidar site by the weather transmitter WXT510 (Vaisala) mounted on the roof platform of the RT-Lab at $21 \mathrm{~m}$ above the ground's surface.

\section{Methodology}

\subsection{Derivation of Optical Properties from Raman Lidar}

The lidar profiles are evaluated using the in-house developed VerlaufNG7.vi software and AOD-PMconvISv2.vi written in LabView Programming Environment. The details on the evaluation scheme can be found in [6] for aerosol optical properties, Stachlewska et al. [5] for aerosol optical depth 
for PM conversion, Stachlewska et al. [50] for water vapour. The daytime extinction and backscattering coefficients and depolarization ratios are derived with a resolution of 20-30 $\mathrm{min}$ and $7.5 \mathrm{~m}$. Prior to the optical quantities retrieval, smoothing with a running m50ean for 49 range bins was applied on the far and near-range raw signals. The water vapour profiles are retrieved only at night-time with a resolution of $30 \mathrm{~min}$ and $7.5 \mathrm{~m}$; during the daytime, skylight is too intense, limiting the detection capacity at $407 \mathrm{~nm}$ [50]. The EARLINET quality assurance procedures are applied on a regular basis [1]. Prerequisites for the retrieval of optical properties from the lidar signals are the clear-sky conditions [6] and the signal-to-noise ratio threshold [51]. For the above-given signal averaging, the value of at least 20 is regarded as sufficient.

As a standard, the particle extinction coefficient profiles were derived at 355 and $532 \mathrm{~nm}$ wavelengths by the application of classic Raman retrieval to the nitrogen channels at 387 and $607 \mathrm{~nm}$. Those were then used to obtain the particle backscattering coefficient at 355, 532 and $1064 \mathrm{~nm}$. The molecular extinction and backscattering coefficient profiles were calculated using the atmospheric pressure and temperature profiles $(\mathrm{p}, \mathrm{T})$ obtained from the radiosounding launches at WMO 12374 station in Legionowo. As a standard, the radiosonde data points (initial sampling frequency of $1 \mathrm{~s}$, translates to $\sim 3.5 \mathrm{~m}$ height resolution) are stored with a non-equidistant height resolution (points with a jump in T). Therefore, between those data points, a linear interpolation to the height resolution of lidar was performed. Additionally, the temperature and pressure at the surface $\left(\mathrm{p}_{0}, \mathrm{~T}_{0}\right)$ from the meteorological station on the roof platform of the RT-Lab was used to reflect the local conditions directly at the lidar site. The uncertainty of the obtained backscattering and extinction coefficients is related mainly to the height dependent signal-to-noise level and applied smoothing, then the assumption of the Ångström exponent for extinction coefficient calculation ( $2 \%$ ) and the molecular backscattering value chosen for the backscattering coefficient calibration (5\%). Thus, the measurement errors are height dependent being at a level of $5 \%$ within boundary layer and $10 \%$ for retrieval heights up to $3 \mathrm{~km}$.

The aerosol optical depth columnar values were obtained by integrating the particle extinction coefficient profiles derived at $355 \mathrm{~nm}$ and $532 \mathrm{~nm}$ (the far and near-range lidar profiles were calculated separately and then merged to decrease the overlap-affected range of extinction profiles down to $450 \mathrm{~m} \pm 30 \mathrm{~m}$ ). In the lower range, the merged extinction profiles were linearly extrapolated to the ground (with the lowermost extinction value obtained), taking into account information at the surface. In the upper range, the extinction profiles were extrapolated exponentially, from the value obtained at the top of the boundary layer, to the theoretical value of the Rayleigh molecular extinction at the tropopause level. The aerosol layers present above the boundary layer top were ignored for altitudes at which the signal-to noise ratio threshold was not fulfilled; otherwise the obtained extinction values were superimposed on the interpolated profiles. The dominating sources of uncertainties of the AOD calculations are related to quality of the retrieval of the particle extinction coefficient profile and the interpolations applied. For the retrievals derived within this paper, the AOD uncertainty within boundary layer is below 20\% (downward interpolation only) and for columnar value it is below $30 \%$ for $\mathrm{AOD}<0.1$ and $25 \%$ for $\mathrm{AOD}>0.1$ (both interpolations).

The particle lidar ratios at $355 \mathrm{~nm}$ and $532 \mathrm{~nm}$ were derived in a standard way as the particle extinction-to-backscattering coefficient ratios with an uncertainty below $35 \%$ within dynamically found boundary layer and below $40 \%$ for retrieval heights up to $3 \mathrm{~km}$.

The particle depolarization ratios at $355 \mathrm{~nm}$ and $532 \mathrm{~nm}$ were derived by using the classic \pm 45 calibration method, as detailed in [45]. The uncertainty of the retrieval for the data derived within this paper, was below $20 \%$ for particle depolarization ratio threshold of $1.5 \%$.

For the retrieval of the boundary layer height two classic methods were used: the Haar wavelet method as described in [52] and the gradient method as shown in [53], which are applied on the range and background corrected lidar signals at three elastic wavelengths. The boundary layer height is computed as the mean height of the three, that allows estimating the uncertainty of the retrieval which is in general below $\pm 40 \mathrm{~m}[54]$. 


\subsection{Aerosol Optical Properties Retrieval from Satellite Sensor}

For the daytime aerosol optical depth retrieval from the SEVIRI instrument, the in-house developed SEVIRI-AOD-Poland_v2.m algorithm, written in a Matlab Programming Environment was used. This algorithm is contributing to a retrieval of SEVIRI AOD over land. A detailed code description along with an extensive sensitivity study can be found in [9]. Recent modifications to this algorithm and a comparative study of the SEVIRI_AOD with the AOD derived from lidar, sunphotometers and radiometers, as well as with model derived AODs, have been reported in [5]. The algorithm is capable of providing in near real-time the AOD maps covering the territory of Poland. The algorithm is fed with the high temporal and spatial resolution radiance measurements from the SEVIRI visible channel $1(635 \mathrm{~nm})$ and allows for deriving AOD at $635 \mathrm{~nm}$, at a spatial resolution of about $5.5 \times 5.5 \mathrm{~km}$ (due to the scan geometry for the area of Poland), at a frequency of $15 \mathrm{~min}$. The assessment of the surface reflectance properties is done on reference days (cloud cover over Poland < 0.6; low AOD < 0.15 at $550 \mathrm{~nm}$ ) based on the top-of-atmosphere reflectance measured by the SEVIRI detector. As the elimination of influence of atmospheric aerosols on the reflectance measured by satellite is essential, an approach based on applying the optimal interpolation method [55] is used with additional ground-based AOD information. The latter is obtained from the AOD forecast data of the Copernicus Atmosphere Monitoring Service (CAMS) [56,57] (http:/ / atmosphere.copernicus.eu), complemented with spectral optical depth measurements at six ground-based sites of the PolandAOD network (www.polandaod.pl) in Sopot, Rzecin, Warsaw, Belsk, Raciborz and Strzyzow. The uncertainty of the derived AOD dependents on a number of contributing factors, being mainly related to the accuracy of the surface reflectance estimation and the optical depth of the atmosphere, discussed in detail in the sensitivity study by [9]. The AOD uncertainty is estimated at the level of $15 \%$ for AODs $>0.2$ and $20 \%$ otherwise, for the data derived within this paper.

\section{General Weather Situation and Air Mass Transport}

The online Weather Service of the Institute of Meteorology and Water Management-The National Research Institute in Poland (IMGW-PIB) is publishes European synoptic maps twice a day for 0:00 and 12:00 UTC at http:/ / www.pogodynka.pl/polska/mapa_synoptyczna. Moreover, the synoptic charts based on the NCEP/NCAR Reanalysis are available for Europe via https:/ / www.esrl.noaa.gov/psd/ data/composites/day of the Earth System Research Laboratory NOAA. According to weather charts of both services, on 24 August 2016, in the lower troposphere, the high-pressure system from Western Europe shifted and settled over Poland; and on its eastern side, a maritime air mass flowed over Warsaw. On the days that followed, the high-pressure system very slowly moved further east towards Belarus and Ukraine, which caused an inflow of air masses from over these countries into Warsaw along the southern and western side of the high-pressure system. At the same time, Europe was under the influence of a warm and dry advection from North-West Africa, with a front (separating the two air masses) running over the northern coast of the continent and Scandinavia. In the free troposphere, a high-pressure wedge extending from West Africa, through Western to Central Europe, caused an inflow of a very warm air mass from the southwest. This situation was very stable until the night of 27/28 August 2016. At midday of 28 August, in the lower troposphere, the front line changed due to the low-pressure system formed west of the British Isles, which then moved fast, eastward through Denmark over the Baltic Sea. As a result, on the two following days, a cold front (spread along the south-west to north-east line) passed through Poland which likely brought moist maritime air mass. At midnight on 29 August, the front was at the north-western tip of Poland, at midday it was located over Warsaw and in the evening of 30 August, it passed the south-eastern tip of Poland.

The near-surface temperature and relative humidity measurements collected by the WXT510 meteorological station in Warsaw and Strzyzow (www.poland.aod.pl) were examined. In general, the temperature record at both sites exhibited for each day a daytime cycle, characterized by lower temperatures at night-time and higher during the day, which was accompanied with an opposite cycle in the relative humidity. For each day at the two sites, the lowest temperatures and highest relative 
humidity (circa $16{ }^{\circ} \mathrm{C}$ and $77 \%$ for Warsaw and circa $15{ }^{\circ} \mathrm{C}$ and $80 \%$ in Strzyzow) were observed in the morning at about 4:00 UCT. The opposite was observed at about $14: 00 \mathrm{UCT}\left(>28{ }^{\circ} \mathrm{C}\right.$ and $<37 \%$ for Warsaw; $>24^{\circ} \mathrm{C}$ and $<45 \%$ in Strzyzow). During the course of events, the maximum temperature in Warsaw on each day was rising gradually from typical summer value of $22^{\circ} \mathrm{C}$ on midday of 24 August, to reach the highest temperature of $30.5{ }^{\circ} \mathrm{C}$ at midday of 29 August. It then dropped down to $22{ }^{\circ} \mathrm{C}$ on 30 August. The daytime relative humidity was very low, with minimal values between only 30-38\% (with a mean for all days of $36.9^{\circ} \mathrm{C}$ ), indicating extremely dry conditions. For all days, the maximum surface temperature obtained in Strzyzow was up to $3-6^{\circ} \mathrm{C}$ lower than in Warsaw but the relative humidity was higher (reading higher up to 3-12\%). At both sites, the daily mean values of temperature and relative humidity followed the same trend as the extreme values.

In Warsaw, for the entire period, the surface wind speed was low $(<4 \mathrm{~m} / \mathrm{s})$, with the daily mean values between $1.2-1.9 \mathrm{~m} / \mathrm{s}$. The predominant wind speed direction was between 300-340 deg (N/NW) on 24 August. On the following day, the wind direction gradually changed from 50 (NE) to 150 deg (S/SE). On 26-28 August it remained at 150-200 deg (S/SW, S, S/SE) and changed back to 300-320 deg (W/NW, NW) on 30 August. In Warsaw, the daily mean values of the surface atmospheric pressure, decreased from $1023.7 \mathrm{hPa}$ to $1010.8 \mathrm{hPa}$ during the consecutive days, whereby the pressure reading was on each day higher of 3-5 hPa over the night than over the daytime (8 to $16 \mathrm{UTC}$ ). In Strzyzow, the surface wind speed was slightly higher $(<6 \mathrm{~m} / \mathrm{s})$ and the surface atmospheric pressure was of 4-6 hPa higher than in Warsaw, otherwise similar features were observed.

In the upper air, the radiosounding data at WMO12374 site in Legionowo $(25 \mathrm{~km}$ North of Warsaw) indicated very strong air subsidence and very dry cloudless conditions, especially for the period starting at 00:00 UTC on 25August until 00:00 UTC on 28 August 2016. Essentially similar profiles were obtained for the WMO 12425 site in Wroclaw (350 km South-West of Warsaw). Alike conditions at the two sites can be attributed as due to the quasi-stationary high pressure system spread over Poland. The dynamic Skew-T plots of radiosounding measurements conducted every $6 \mathrm{~h}$ over Warsaw are available via the Atmospheric Sounding Website of the University of Wyoming (http:/ / weather.uwyo.edu/cgi-bin/sounding?region=europe\&TYPE=GIF\%3ASKEWT\& YEAR=2016\&MONTH=08\&FROM=2500\&TO=2800\&STNM=12374).

The air mass backward-trajectories of the NOAA Hybrid single particle Lagrangian Integrated Trajectory (HYSPLIT) model [58,59] available via READY system of the Atmospheric Research Lab (https: / ready.arl.noaa.gov) were used to assess the air mass transport pathways. The plots depicting $48 \mathrm{~h}$ backward-trajectories arriving at 00:00 and 12:00 UTC at altitudes of 0.5, 1.5 and $3 \mathrm{~km}$ were calculated with vertical velocities of meteorological data from the Global Data Assimilation System (GDAS) for four sites of the Poland AOD network, located as follows: Sopot (a semi-urban site at the Baltic Sea cost, northern Poland), Rzecin (a rural wetland site in the Greater Poland Leakland; west-central Poland), Warsaw (an urban site in the Mazovian Lowland; east-central Poland) and Strzyzow (a background mountain site in the Eastern Carpathians; south-eastern Poland).

The $48 \mathrm{~h}$ backward-trajectories calculated at these four sites for the entire period of interest, (24-30 August 2016) are available as quick-looks via the PolandAOD Website (http: / / www.igf.fuw.edu. pl/ kmark/PolandAOD/PolandAODdata.php?date=2016-08-24\&type=15\&lev=1\&next=0\&stat=0). In general, similar air mass transport pathways in the upper boundary layer and free troposphere were observed at each site within this period of time.

Additionally, the $96 \mathrm{~h}$ backward-trajectories for the Warsaw site, calculated at midnight of 24, 27 and 30 August at 0.5, 1 and $1.7 \mathrm{~km}$ (not shown for brevity), revealed for the period of 25-29 August, unlike for the other two days (24 and 30 August), the high pressure system dominating the situation on the large temporal scale. On 24 August, the air masses were spatially well separated within the boundary layer, bringing at lowermost $0.5 \mathrm{~km}$, the air advected very quickly from over Northern France, passing North-East Germany and the Polish Baltic Sea coastline before reaching Warsaw. At 1 and $1.7 \mathrm{~km}$, the air was transported from over the Atlantic, passing the southern and northern 
United Kingdom, respectively. On 30 August, the air mass transport was uniform from over the North Sea, passing Denmark and the northern tip of Germany, before reaching Warsaw.

Moreover, the HYSPLIT backward-trajectories were run with vertical velocity of CDC1 meteorological data, starting in Warsaw at 00:00 UTC for each consecutive day of the event and plotted on one figure. This allowed for assessment of the spatial extent of the air mass transport. The air masses arriving within the boundary layer $(100 \mathrm{~h}$ at $1 \mathrm{~km})$, approximately at its top (100 h at $1.8 \mathrm{~km})$ and in the free troposphere $(130 \mathrm{~h}$ at $2.5 \mathrm{~km})$ were tracked. As the results for 1 and $1.8 \mathrm{~km}$ were qualitatively very similar, in Figure 1, the model runs for $1 \mathrm{~km}$ (within the boundary layer) and $2.5 \mathrm{~km}$ (in the free troposphere) are depicted.

The slower and significantly more-uniform and strongly subsiding air masses that were reaching Warsaw at $1 \mathrm{~km}$ brought the air that was originating at high altitudes (4-6 km) over sub-Arctic Europe (Figure 1, left subplot). The faster air masses, arriving at $2.5 \mathrm{~km}$ (Figure 1, right subplot), brought the air from lower altitudes of the free troposphere $(2-5 \mathrm{~km})$, originating in the vicinity of the Iberian Peninsula. The air mass coming from over Portugal passed Channel La Manche, Southern Scandinavia, then the Baltic republics, Belarus, Ukraine and Slovakia before its arrival in Warsaw. Regardless of the trajectory arrival altitude, the air masses on each consecutive day followed the circulation pattern along the high-pressure system, which was very slowly moving eastward. Moreover, on 25-27 August, the air masses remained stagnant over North-Eastern Europe (the Baltic republics, western region of Belarus and Ukraine and eastern part of Slovakia and Poland).
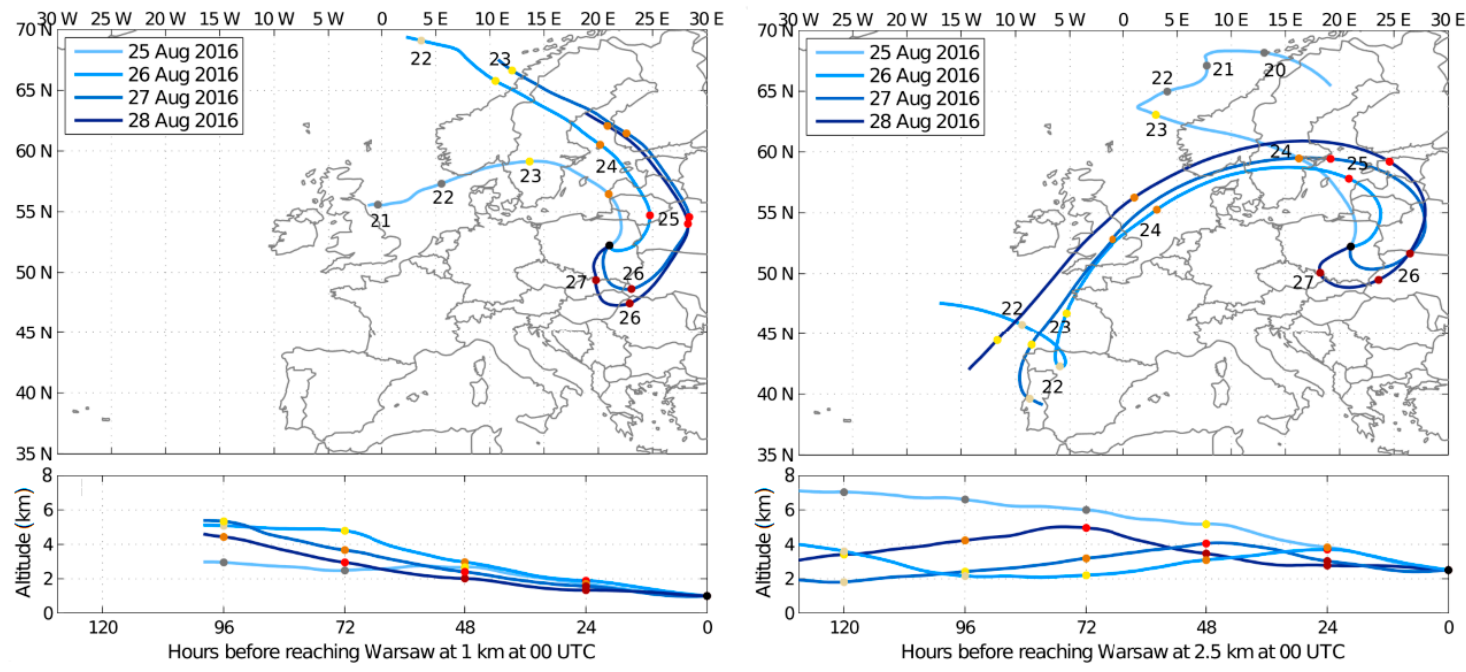

Figure 1. The HYSPLIT backward-trajectories for Warsaw run for $100 \mathrm{~h}$ at $1 \mathrm{~km}$ in the boundary layer (left) and for $130 \mathrm{~h}$ at $2.5 \mathrm{~km}$ in the free troposphere (right) with CDC1 meteorological data reanalysis. Trajectories are starting at 00:00 UTC on consecutive days of the event: 25, 26, 27 and 28 August 2016. The air masses reaching Warsaw at $1 \mathrm{~km}$ were slower and brought air originating in sub-Arctic Europe. The faster air masses arriving at $2.5 \mathrm{~km}$, brought air from the vicinity of the Iberian Peninsula (data source: READY system, Atmospheric Research Lab, NOAA, https:/ / ready.arl.noaa.gov).

Finally, the dispersion backward-trajectories were calculated for consecutive days of the event at Warsaw and Strzyzow. The obtained plots on each day were very similar (not shown for brevity) at the two sited, except for 27 and 28 August, where the likely air mass transport from over the Iberian Peninsula was reaching the Warsaw site (the transport was manifested more strongly on the second day) but not the Strzyzow site. 


\section{Results-Optical Properties of Aerosols}

\subsection{Active Remote Sensing Observations from Satellites and at Ground}

Active remote sensing measurements were performed at three sites of the Poland AOD network in already-introduced Warsaw and Strzyzow, as well as in Raciborz located in the vicinity of the coal industry region of Silesia (Western Carpathians, south-western Poland). In Figure 2, the PollyXT lidar measurements in Warsaw and the CHM15k ceilometer measurements in Strzyzow and Raciborz are shown for the period of 24-30 August 2016.

In Warsaw, on 26-28 August, untypical for summer conditions, aerosol load and the boundary layer top can be discerned from 24/7 evolution plots of the lidar signal (Figure 2a). In general, at night-time in central Europe, convection processes are not expected-typical night-time boundary layer height over Warsaw in August is $<1.5 \pm 0.2 \mathrm{~km}$ a.g.l. [54]. However, during the daytime, the top of the boundary layer can reach $2.9 \pm 0.6 \mathrm{~km}$ a.g.l. due to the occurrence of strong convection [60] and heat waves [5]. For the case of measurements depicted in Figure 2a, the aerosol was confined to the lowermost $1.0 \pm 0.2 \mathrm{~km}$ a.g.l. in the morning of 26 August, then the boundary layer top gradually increased to $1.35 \pm 0.1 \mathrm{~km}$ the following morning, to reach $1.7 \pm 0.2 \mathrm{~km}$ in the morning of 28 August. The maximum of the aerosol load was recorded in the evening of 28 August at $2.0 \pm 0.1 \mathrm{~km}$. The gradual increase of the boundary layer top between 27 and 28 August 2016 was quite dynamic (approximately $1000 \mathrm{~m}$ within less than 2 days!), indicating possible accumulation of not only local pollution but also transported into Warsaw boundary layer biomass burning particles (compare with trajectories in Figure 1). The observed mixing layer height on the days that followed, of 1.1, 1.6 and $2.1 \mathrm{~km}$ a.g.l. was rather low for Warsaw summer conditions (the latter value is more typical for summertime, although still relatively low). At night, the residual layer was exceptionally strong; there were almost no differences in night-time-to-daytime conditions in terms of both layer height (as it was persistently occurring up to the same altitude) and aerosol abundance (less evident). The morning transitions were relatively weak, with no distinct structures within (except for the morning of 27 August). For the case discussed here, the gradual increase of both the aerosol load and the boundary layer top certainly was related to large-scale displacement of the high-pressure system, although this could not have been dominating cause, as it did not manifest at the two other sites in Strzyzow and Raciborz. Over Warsaw, for period starting in the evening of 25 August until the evening of 28 August, there was no evidence of clouds, except for a few passing cumulus, forming over the boundary layer in the evening of 28 August. In free troposphere, there was a clear indication of an aerosol layer at $2.5-3 \mathrm{~km}$ from approximately 5:00 to 12:00 UTC on 26 August, which was likely long-range transported from the vicinity of the Iberian Peninsula (compare with backward trajectories Figure 1). The features visible up to $3 \mathrm{~km}$ on 29 August, are related to aerosols and clouds, caused by the atmospheric front passing over Poland. As for the other days, some cloud signatures are evident, especially for 24 and 30 August.

In Strzyzow, the 24/7 ceilometer data on 26-28 August (Figure 2b) also revealed no clouds, the aerosol load on three days showed an accumulation of particles in the lowermost $0.7 \pm 0.2 \mathrm{~km}$ a.g.l. with slight increase of the boundary layer top at night-time to $0.9 \pm 0.2 \mathrm{~km}$. Morning transitions were not discernible but there was some temporal variability of the aerosol load within the boundary layer. In the free troposphere, there was an indication of a very weak, lofted aerosol layer in the evening of 28 August. On other days, similar cloud signatures as in Warsaw are evident, except for 29 August when even precipitation was evident.

As for the 24/7 ceilometer observations at the Raciborz site (Figure 2c), on 26-28 August, the aerosol load was confined to the lowermost $1.1 \pm 0.1 \mathrm{~km}$ a.g.l. and there was no gradual increase of the boundary layer. The height of the afternoon's aerosol mixing layer and the residual layer at night were almost the same, the latter being of only $200 \mathrm{~m}$ lower. On each day, a rather weak morning transition was discernible. There was a relatively low variability of structures within the boundary layer, indicating possible local and/or transported aerosol accumulation on 28 August (reddish values) with no increase of boundary layer top. No clouds were observed over the site in this 
period. The feature observed in free troposphere at 2-2.5 km on the evening of 28 August (15:00 to 21:00 UTC) should be attributed to an aerosol layer, rather than a cloud system. On other days, similar cloud signatures as in Warsaw and Strzyzow are evident, with some precipitation signatures driven by passing front on 29 August.

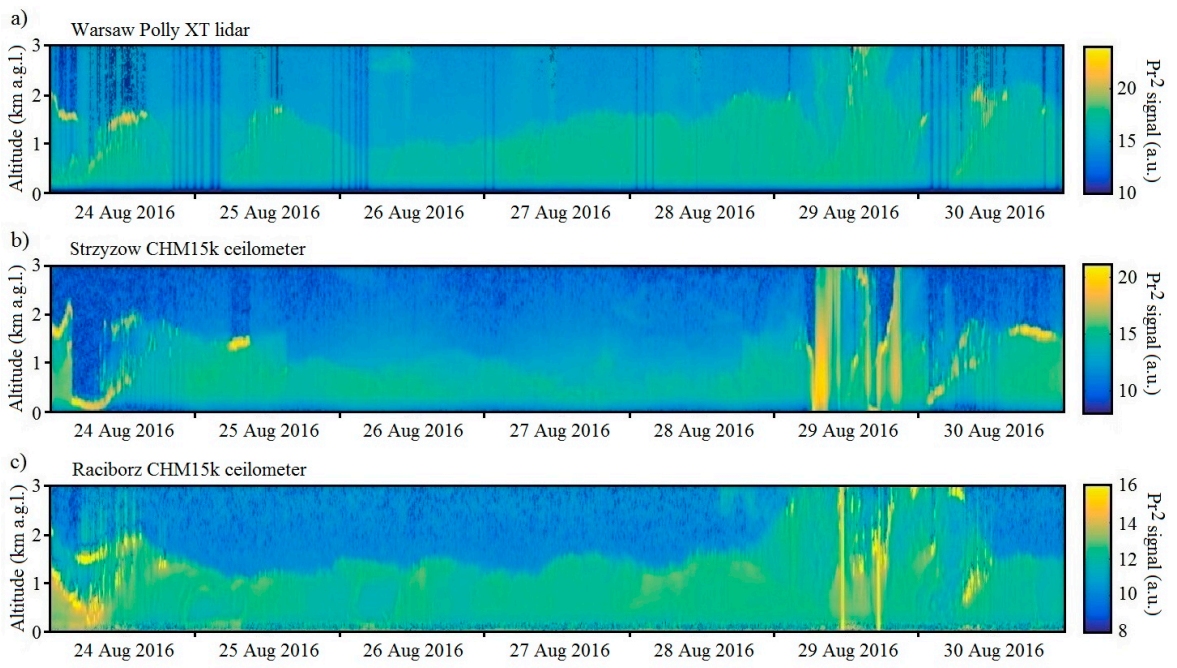

Figure 2. Remote 24/7 measurement conducted on 24-30 August 2016. Range and background corrected signal at $1064 \mathrm{~nm}$ of (a) the PollyXT lidar at the RT-Lab in Warsaw (central Poland) and (b) CHM15K ceilometer measurements at SolarAOT Observatory in Strzyzow (south-eastern Poland) and (c) IGF-PAS Observatory in Raciborz. High signal intensities are denoted with the yellow colour and low with blue. Note different scale of the plots.

In general, low signal-to-noise ratio at relatively large wavelengths, deployed for the sake of eye-safety in ceilometers, limits the scope of available instrument products [60]. Moreover, despite efforts at exploiting single-wavelength elastic backscattering lidar/ceilometer data for the aerosol optical properties retrieval, such as a co-location with photometer AOD [51], a constrain with satellite AODs [61], a forward retrieval [62,63] or a two-stream approach [64], significant limitations have been reported. Therefore, analyses within the current paper were primarily focused on solely and independently derived, vertically-resolved aerosol optical properties from the complex, multiwavelength, far and near-range PollyXT lidar ground-based observations over the Warsaw EARLINET site. The observations provided a unique set of aerosol wavelength-dependent optical properties: particle extinction $(2 \alpha)$ and backscattering $(3 \beta)$ coefficient, linear particle depolarization ratio $(2 \delta)$.

In total, 33 day-time and night-time profiles were obtained for the investigated period, from 24 to 30 August 2016. The sets of $2 \alpha+3 \beta+2 \delta$, were inspected visually and divided into 4 time periods in which the similarity of the consecutive profiles was high: the night of 25/26 August, the late afternoon and early evening of 26 August, the night of 26/27 August and the night of 27/28 August. The mean aerosol properties (with their variance indicated by shadows), plotted in Figure 3, depict the variability of the obtained results. Although according to the synoptic weather charts during this period a quasi-stationary situation was expected, clearly different aerosol properties were observed in the four groups as well as within the boundary layer and in the free troposphere.

In general, on both first panels in Figure 3 (the night of 25/26 August and the daytime of 26 August), both particle extinction coefficient profiles were very similar, if not the same, within the given uncertainties. However, for the last two panels (the nights of 26/27 and 27/28 August) this holds true only for the free troposphere range, as the extinction profiles were clearly higher at $355 \mathrm{~nm}$ within the boundary layer. Moreover, the extinction coefficient peak visible in the free troposphere at the first night seems to lower with altitude and time to appear within the boundary layer at the last night. 
The particle depolarization above $1.4 \mathrm{~km}$ was clearly separated at the two wavelengths (with higher values at $355 \mathrm{~nm}$ ) at the night of 25/26 August and at the daytime of 26 August. On the following two nights, the particle depolarization at both wavelengths was the same within the given uncertainty range (with a slight tendency for higher values at $532 \mathrm{~nm}$ ). Within the boundary layer, the depolarization ratio at $532 \mathrm{~nm}$ was always higher than its value at $355 \mathrm{~nm}$, both being the highest at the daytime of 26 August. As for the Ångström exponent, it was always significantly lower in the free troposphere than within the boundary layer, except for the daytime of 26 August 2016, when it became higher. The lidar ratio at $355 \mathrm{~nm}$ clearly decreased with altitude in all cases depicted in Figure 3, however, the lidar ratio at $532 \mathrm{~nm}$ did not revealed such clear regularity, which is visible especially at night of 25/26 and 26/27 August.
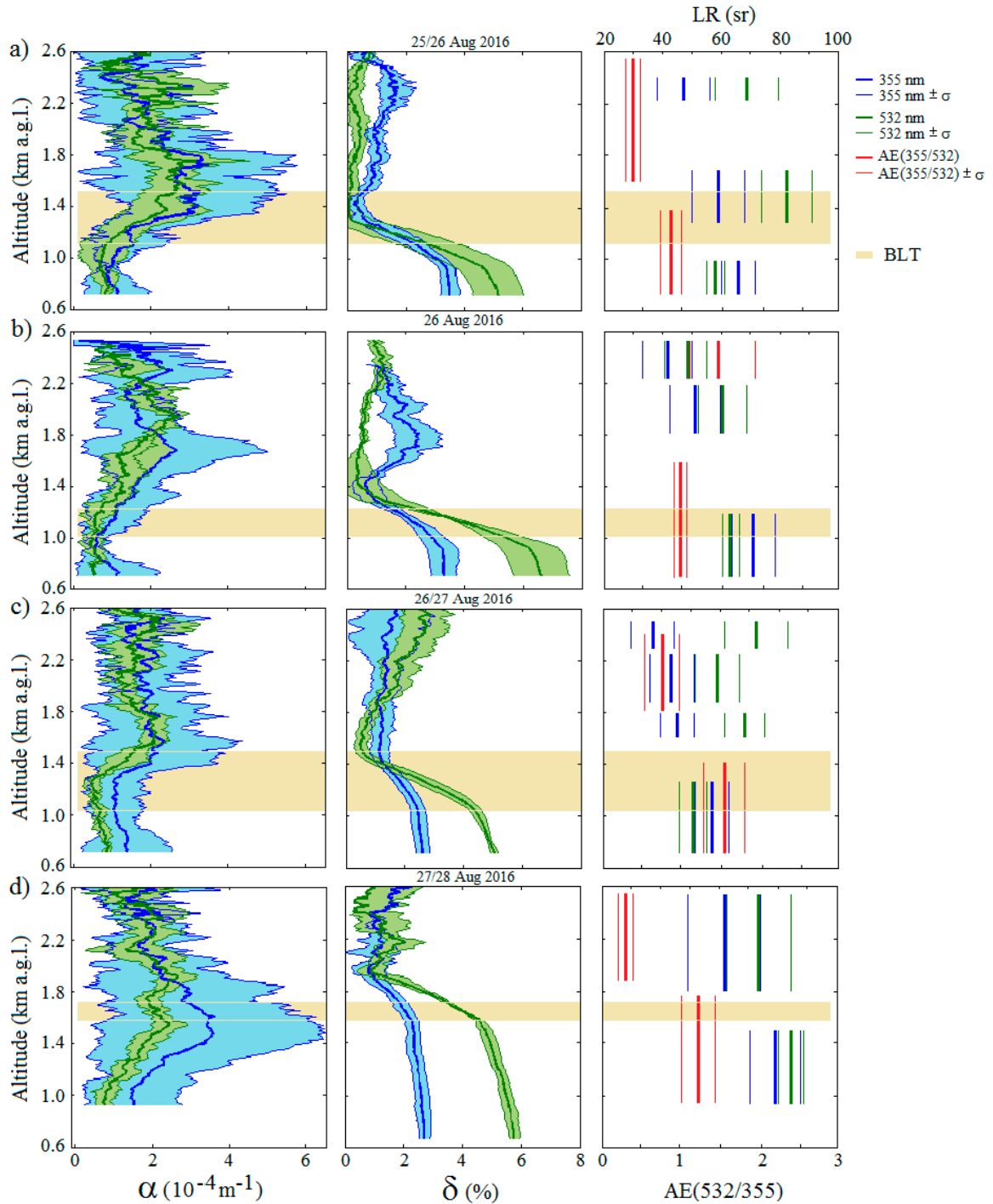

Figure 3. Mean optical properties of aerosols over Warsaw derived from the PollyXT lidar data for (a) the night of 25/26, (b) the daytime of 26, (c) the night of 26/27 and (d) the night of 27/28 August 2016 during quasi-stable weather conditions. Left column depicts particle extinction coefficient profiles $(\alpha)$ derived using the Raman method for $355 \mathrm{~nm}$ (in blue) and $532 \mathrm{~nm}$ (in green). Middle subfigures show linear particle depolarization ratio profiles $(\delta)$ for the two wavelengths (blue/green). The right subfigures depict the extinction-related Ångström exponent (AE) obtained for the two wavelengths (in red, bottom scale), as well as lidar ratio at $355 \mathrm{~nm}$ and $532 \mathrm{~nm}$ (in blue/green, top scale). The boundary layer height range is indicated with beige. 
In Figure 3, on the night of 25/26 August (top subfigures), within the boundary layer, below $1.1 \mathrm{~km}$ significant wavelength dependence for the mean depolarization ratio (being of roughly $3.4 \%$ for $355 \mathrm{~nm}$ and higher of $5.2 \%$ for $532 \mathrm{~nm})$ with the mean extinction profiles $\left(\sim 1 \cdot 10^{-4} \mathrm{~m}^{-1}\right.$ for $355 \mathrm{~nm}$ and $\left.532 \mathrm{~nm}\right)$ can be discerned. The mean Ångström exponent was relatively low ( 0.9) and the lidar ratio at $355 \mathrm{~nm}$ (68 sr) was higher than for $532 \mathrm{~nm}(60 \mathrm{sr})$. At the height of 2.2-2.5 km, in the free troposphere, the mean Ångström exponent was low ( 0.4), the lidar ratio at $355 \mathrm{~nm}$ (46 sr) was lower than for $532 \mathrm{~nm}$ (70 sr) and the linear depolarization ratio at $355 \mathrm{~nm}$ was slightly increased to a value of about $1.6 \%$.

During the day of 26 August, within the boundary layer, similar profiles were derived, whereby significant wavelength dependence in depolarization ratio (roughly $3.1 \%$ for $355 \mathrm{~nm}$ and higher of $6.5 \%$ for $532 \mathrm{~nm}$ ) was captured. The mean Ångström exponent $(\sim 1)$ and the lidar ratio at $355 \mathrm{~nm}(70 \mathrm{sr})$ and $532 \mathrm{~nm}(60 \mathrm{sr})$ were slightly higher than at night. In the free troposphere, the mean Ångström exponent was high (1.5), the lidar ratio at $355 \mathrm{~nm}$ (40-50 sr) was lower than for $532 \mathrm{~nm}$ (50-60 sr) and the linear depolarization ratio at $355 \mathrm{~nm}$, was still slightly increased (up to $2.5 \%$ ).

On the night of 26/27 August, separation of the properties in free troposphere and within the boundary layer was still visible. Within the boundary layer the Ångström exponent increased to 1.6 and the depolarization ratio and lidar ratio at both wavelengths decreased $(2.4 \%, 56 \mathrm{sr}$ and $4.8 \%$, $50 \mathrm{sr}$ at 355 and $532 \mathrm{~nm}$, respectively). In the upper range, above $1.8 \mathrm{~km}$ depolarization at $532 \mathrm{~nm}$ increased and lidar ratios at both wavelengths as well as Ångström exponent slightly decreased.

During the following night, 27/28 August, within the boundary layer, a similar relation of the lidar ratio as in the free troposphere is striking (reversed wavelength dependence). High lidar ratios of 80 sr and 83 sr for 355 and 532 were derived for a significantly high Ångström exponent (1.2) and with depolarization ratios of $2.3 \%$ for $355 \mathrm{~nm}$ and higher, of $5.9 \%$ for $532 \mathrm{~nm}$, the latter being higher as on the previous night. In the free troposphere, Angström exponent was relatively low ( 0.3) with significantly high lidar ratios at $355 \mathrm{~nm}$ (60 sr) being higher than for $532 \mathrm{~nm}$ (72 sr).

The optical properties derived within the boundary layer and the free troposphere are listed in Table 1. Within the boundary layer, local aerosol properties were likely affected by 1-2 day-old biomass burning transport from over Ukraine (compare Figure 1, left subfigure). The obtained Ångström exponent (1-1.5) indicated moderately fresh aerosol. The values of $\sim 1.9$ for very fresh and $<1$ for aged biomass burning are reported $[13,65]$. The significant wavelength dependence of the mean depolarization ratio was similar in the current study to those reported for biomass burning by $[7,25]$. The ratio of lidar ratios $\left(\mathrm{LR}_{355} / \mathrm{LR}_{532}\right)$ was close to 1 ; for moderately fresh biomass burning values of 1 or higher can be expected [13].

At the height of $2-2.5 \mathrm{~km}$, the free troposphere was likely influenced by the long-range transported intrusion of 3-5 day-old biomass burning aerosol from over Portugal (compare Figure 1, right subfigure). The reversed wavelength dependence for the mean lidar ratio ( $45 \mathrm{sr}$ at $355 \mathrm{~nm}$ and $\sim 65 \mathrm{sr}$ at $532 \mathrm{~nm}$ ) characteristic for aged biomass burning was discerned. The reversed dependence in the lidar ratio reported by [7,13] was of about $30 \mathrm{sr}$ at $355 \mathrm{~nm}$ and $55 \mathrm{sr}$ at $532 \mathrm{~nm}$. In [24,25] higher values of about $60 \mathrm{sr}$ and $90 \mathrm{sr}$ were reported, respectively. The depolarization ratio values are similar to those reported by [25], for the case of the biomass burning layers with low particle abundance. The obtained Ångström exponent $(<1)$ was typical for aged biomass burning aerosol, as in $[13,65]$.

As for detailed interpretation of the tropospheric layers, they seem to attribute on the following 4 time periods to: (a), (c), (d) the low in abundance, aged, 3-5 day-old forest fire biomass burning from Portugal and (b) the likely mixture of the aged, 3-4 day-old Portuguese biomass burning with the moderately-fresh, $<1$ day-old peatland fire biomass burning form Ukraine.

In the layers defined within the boundary layer, the detailed interpretation is as follows: (a), (b) and (c) a slight local, background urban pollution affected with an intruding Ukrainian biomass burning, being at first moderately-fresh $<1$ day old, then 1-2 day old and (d) mixture of the 2 day-old Ukrainian with the aged 3-4 day-old Portuguese biomass burning. 
Table 1. Optical properties derived from the PollyXT lidar over Warsaw within the boundary layer and in the free troposphere on 25-28 August 2016.

\begin{tabular}{|c|c|c|c|c|c|c|}
\hline Date & Altitude (km) & $\mathbf{L R}_{355}$ (sr) & $\mathrm{LR}_{532}(\mathrm{sr})$ & $\mathrm{AE}(355 / 532)$ & $\mathrm{DR}_{355}(\%)$ & $\mathrm{DR}_{532}(\%)$ \\
\hline \multicolumn{7}{|c|}{ free troposphere: aged, 3-5 day-old, biomass burning (forest fires), Portugal } \\
\hline 25/26 Aug 2016 & $2.2-2.4$ & $46.7 \pm 9.3$ & $67.9 \pm 10.2$ & $0.38 \pm 0.11$ & $1.6 \pm 0.2$ & $0.3 \pm 0.1$ \\
\hline 26 Aug 2016 & $2.25-2.6$ & $41.6 \pm 8.3$ & $48.2 \pm 7.2$ & $1.49 \pm 0.30$ & - & $1.1 \pm 0.1$ \\
\hline 26/27 Aug 2016 & $1.85-2.25$ & $43.1 \pm 7.5$ & $59.2 \pm 7.4$ & $0.76 \pm 0.23$ & $1.1 \pm 0.1$ & $1.8 \pm 0.2$ \\
\hline 27/28 Aug 2016 & $2-2.5$ & $61.7 \pm 12.3$ & $73.2 \pm 11.0$ & $0.34 \pm 0.10$ & $1.1 \pm 0.1$ & $1.4 \pm 0.2$ \\
\hline \multicolumn{7}{|c|}{ boundary layer: moderately fresh, $<1-2$ day-old biomass burning (peatland/grass fires), Ukraine } \\
\hline 25/26 Aug 2016 & $0.7-1$ & $66.7 \pm 6.7$ & $58.3 \pm 2.9$ & $0.87 \pm 0.13$ & $3.4 \pm 0.4$ & $5.0 \pm 0.6$ \\
\hline 26 Aug 2016 & $0.7-1$ & $70.8 \pm 7.1$ & $62.7 \pm 3.1$ & $0.97 \pm 0.15$ & $3.1 \pm 0.4$ & $6.5 \pm 0.8$ \\
\hline 26/27 Aug 2016 & $0.7-1.2$ & $56.5 \pm 5.7$ & $50.6 \pm 5.1$ & $1.54 \pm 0.23$ & $2.4 \pm 0.3$ & $4.8 \pm 0.5$ \\
\hline 27/28 Aug 2016 & $0.9-1.4$ & $79.2 \pm 7.9$ & $84.3 \pm 4.2$ & $1.23 \pm 0.18$ & $2.4 \pm 0.3$ & $5.3 \pm 0.7$ \\
\hline
\end{tabular}

The yearly mean and the summer mean (JJA) particle extinction profiles were calculated at $355 \mathrm{~nm}$ and $532 \mathrm{~nm}$ based on four years (2013-2016) of observations at the Warsaw site. The mean profiles were obtained by averaging profiles available within the category climatology of the EARLINET/ACTRIS Data Base (accessed on 26 January 2018 via www.earlinet.org). In this category, only data files derived for the Monday evening and Thursday midday and evening measurements are stored. In total 68 and 24 profiles were averaged to obtain the yearly mean and the summer mean, respectively. The climatology profiles with standard deviation are shown in Figure 4.

The mean particle extinction coefficient profiles derived over Warsaw during stable weather conditions on 25-28 August depicted in (Figure 3) showed differences in signatures in comparison with the mean profiles derived for the summer season (Figure 4, in purple). The characteristic extinction peak at about 1.4-2.2 km altitude visible in the mean summer profiles at both wavelengths (up to roughly $2.4 \cdot 10^{-4} \mathrm{~m}^{-1}$ at $355 \mathrm{~nm}$ and $1.3 \cdot 10^{-4} \mathrm{~m}^{-1}$ at $532 \mathrm{~nm}$ ), was also visible in Figure 3 . In both figures, within the boundary layer (up to 1-1.8 km), the extinction at $355 \mathrm{~nm}$ was higher than at $532 \mathrm{~nm}$ but above there was not much wavelength dependence in Figure 3. By comparison, in the mean summer profiles, the wavelength dependence is observed regardless of altitude, with the mean summer extinction coefficients being higher at $355 \mathrm{~nm}$ than at $532 \mathrm{~nm}$.

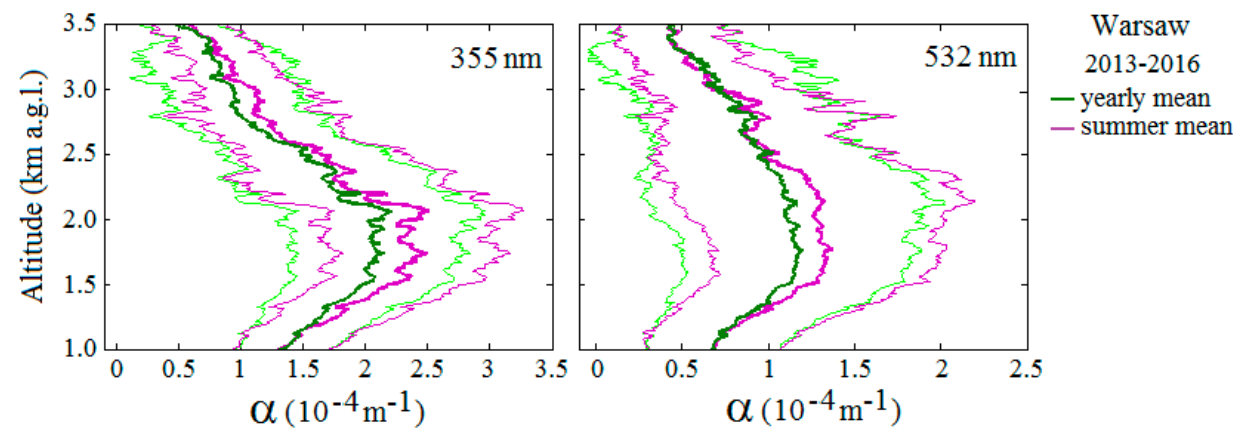

Figure 4. Mean particle extinction coefficient profiles over Warsaw derived from data files available within the EARLINET/ACTRIS data base from 2013 till 2016. The mean climatology profile (in green) and the mean summer profile (in purple) were derived from PollyXT lidar signals using the Raman approach at $355 \mathrm{~nm}$ (left) and $532 \mathrm{~nm}$ (right) (data source: www.earlinet.org).

The temporal evolution of the lidar-derived aerosol properties within the boundary layer during the analysed period is given in Figure 5, where along with the boundary layer height, the extinction-related Ångström exponent derived at 355 and $532 \mathrm{~nm}$, as well as wavelength dependent aerosol optical depth, particle lidar ratios and particle depolarization ratios are depicted. An opposite trend in the lidar ratio and Ångström exponent is weakly manifested but still discernible, 
as expected. The scatter plot of the extinction related Ångström exponent (355/532) and lidar ratios at both wavelengths revealed similar relations, indicating decreasing lidar ratios for high values of Angström exponent (negative correlation coefficient was low of -0.4 and -0.3 for $532 \mathrm{~nm}$ and $355 \mathrm{~nm}$, respectively). Lower lidar ratios were obtained for the evening of 26 till the morning of 27 August (40 sr to $60 \mathrm{sr}$ ). In general, lower depolarization ratios are obtained for $355 \mathrm{~nm}$ (1.6 to $4 \%$ ) than for $532 \mathrm{~nm}$ wavelength (4 to 7.5\%) for the same Ångström exponent, whereby the highest depolarizations were observed in the evening of 26 August (6 to 8\%). Similar tendencies as for lidar ratio, seem visible in the relation between the extinction related Angström exponent $(355 / 532)$ and linear depolarization ratio at the two wavelengths, i.e., decreasing depolarization ratios were obtained for increasing Ångström exponent values, whereby this being significantly weaker at $355 \mathrm{~nm}$. The increase of the boundary layer height seems to be in general accordance with the increase of the aerosol optical depth and Ångström exponent. Increasing Ångström exponent was observed on the evening of 26 August onward, reaching its highest values in the morning of 27 August. At the same time period, the lidar ratio had lowest variability. The depolarization ratio revealed significant differences at the beginning of the evening of 26 August; before and after, the differences were at a similar level.

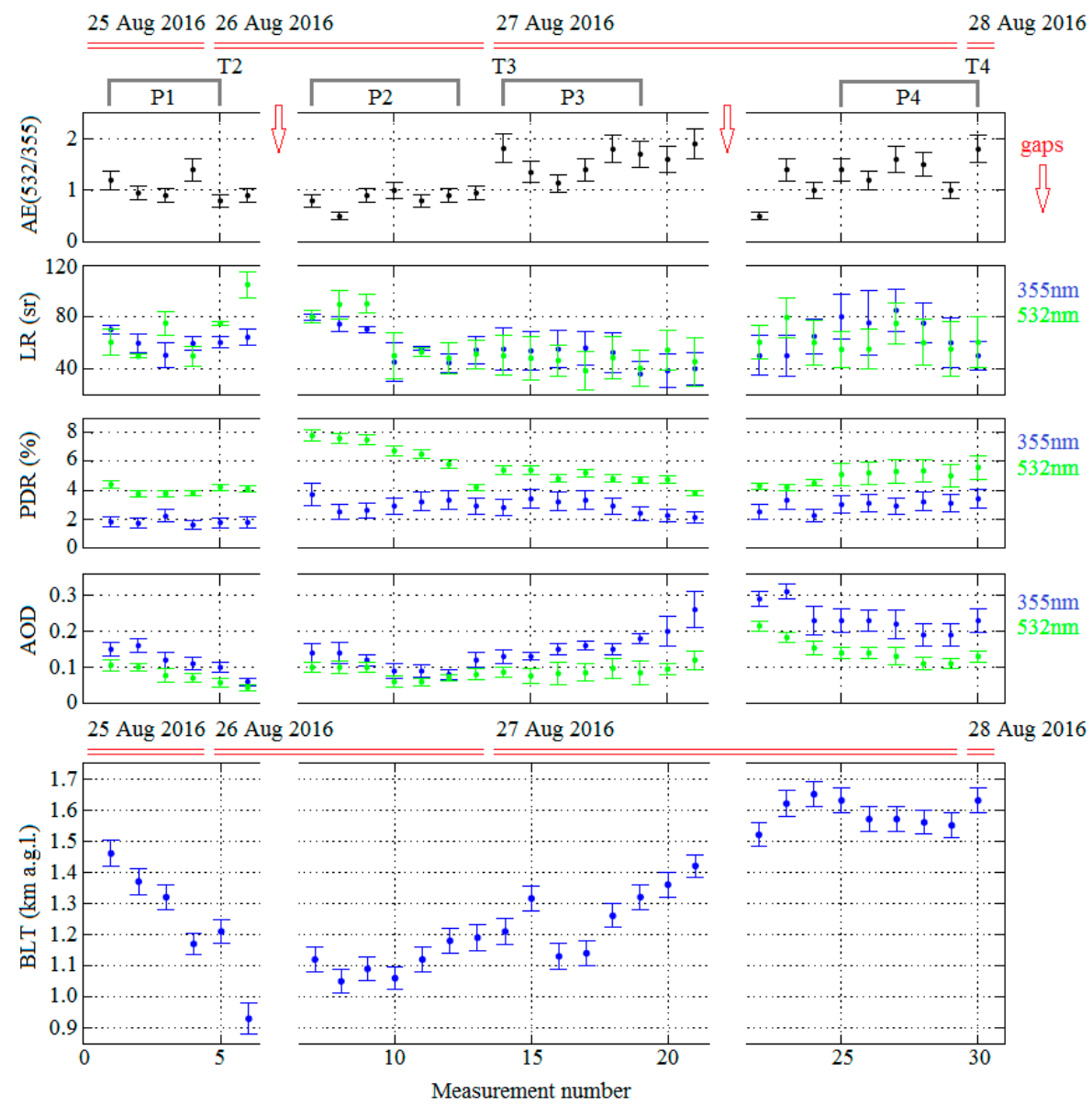

Figure 5. Temporal evolution of lidar-derived extinction related Ångström exponent AE(355/532), lidar ratios (LR), particle depolarization ratios (PDR), aerosol optical depth (AOD) at $355 \mathrm{~nm}$ (in blue) and $532 \mathrm{~nm}$ (in green) and the corresponding boundary layer top (BLT) derived with the PollyXT lidar data on 25-28 August 2016 over Warsaw. Note the two data gaps (arrows) of 12 and $10 \mathrm{~h}$, consecutively. Red lines indicate the measurement day. The starting time for the backward trajectory calculation (T2-T4) depicted in Figure 1 is marked. Grey brackets indicate the time period used for calculating averaged profiles (P1-P4) depicted in Figure 3. 
As for the satellite active remote sensing, within the analysed time period of 24-30 August 2016, the Cloud-Aerosol Transport System (CATS) products over the Warsaw site, were available only on the first and the last day of the analysed period. They were used to indicate conditions before and after the high-pressure situation. The CATS overpasses at a distance regarded sufficiently close to the Warsaw lidar site were chosen according to the EARLINET inter-comparison rules. The L2-products for 24 and 30 August 2016, available via the CATS Website (https: / / cats.gsfc.nasa.gov), include the backscattering coefficient at $1064 \mathrm{~nm}$, the particulate depolarization ratio at $1064 \mathrm{~nm}$ and the feature type and aerosol subtype for atmospheric layer classifications. For the Warsaw CATS overpass on 24 August (11:28 UTC; $44.85 \mathrm{~km}$ closest orbital distance), a dust-clean continental aerosol layer coexisting with water clouds was detected at an altitude of approximately 1-3 km a.g.1. On 30 August (09:26 UTC; 53.06 km closest orbital distance) at about $2-3 \mathrm{~km}$, the backscattering and particle depolarization ratio showed a polluted dust aerosol subtypes. On both days, the lidar data was available $24 \mathrm{~h} /$ day and for 24 August indicated a thin, liquid water cloud signature, building on the boundary layer top, sensed at about $1.8 \mathrm{~km}$; and for 30 August, a strongly depolarizing aerosol, apart from weak and scattered clouds, accompanying the morning transition in the boundary layer.

Mineral dust intrusions often accompanied by cloud systems are not uncommon over Warsaw [37] and cannot be excluded in this case. This could be positively confirmed with AERONET measurements. Dust-dominated conditions are defined when the AREONET Level 2.0 Ångström exponent $(440 / 870)$ is less than or equal to $0.75[66,67]$. Unfortunately, for the entire investigated period of 24-30 August 2016, there was no Level 2.0 AERONET data available for the Belsk site, being the closest to Warsaw (40 km distance). Therefore, the lidar-derived Ångström exponent (355/532) on 24 and 30 August was used instead. Values in the range of 0.6-0.8 and 0.4-0.8 were obtained, which on both days indicated the existence of relatively large particles that could have been related to dust or other large-sized aerosol (e.g., pollen, reported by [68]). These values are significantly lower in comparison to the Ångström exponent (355/532) of roughly 0.8 to 1.8 on 25-27 August (compare with Figure 5) during the intrusion of biomass burning particles into the boundary layer. The lidar-derived depolarization profiles can serve as a good indication on particle shape used for separation of the mineral dust from other aerosol types. An increased depolarization of up to $12 \%$ was observed in the lidar data but only within the boundary layer on 29 and 30 August, which supports the interpretation of the observed features such as pollen and not dusts mixtures.

\subsection{Passive Remote Sensing from Satellites and at the Ground Level}

The SEVIRI AOD maps covering the entire area of Poland were obtained every $15 \mathrm{~min}$, on each day of the analysed period. There is a lack of maps on 26 August, as this day was suitable for a as reference day, exhibiting the lowest cloud coverage and the lowest aerosol optical depths. Air mass transport for this day showed possible contamination with biomass burning but considering the transport on all other days, this day was the best candidate. Moreover, the maps cannot be provided for the night-time or for high and low Sun elevation angles. Very high cloud coverage over Poland on 24 August prevented the retrieval on this day. For the remaining days, the retrievals proved successful. In total, 98 maps were derived (for brevity, only selection of those can be shown). The SEVIRI AOD Maps are depicted in Figure 6. 

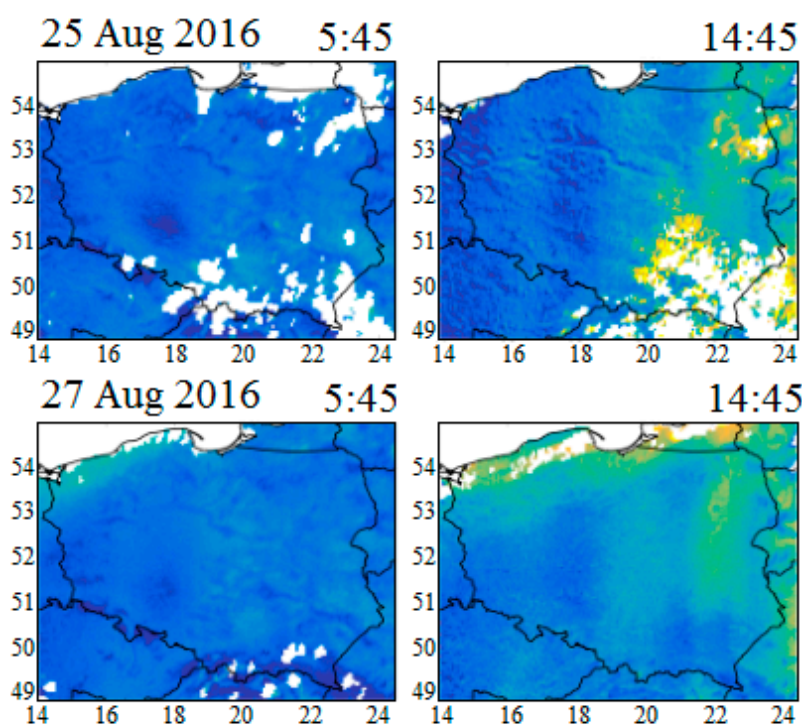

$14: 45$
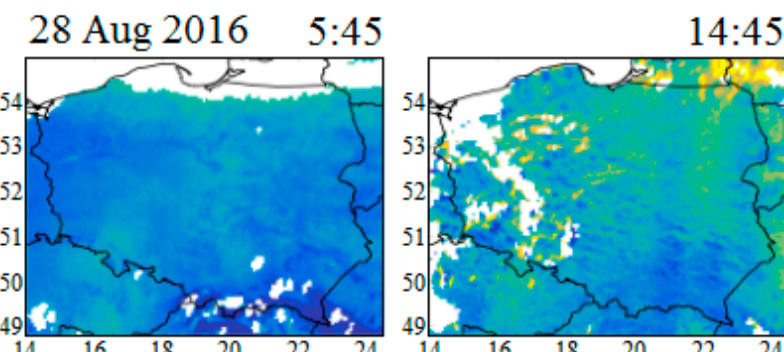

$14: 45$
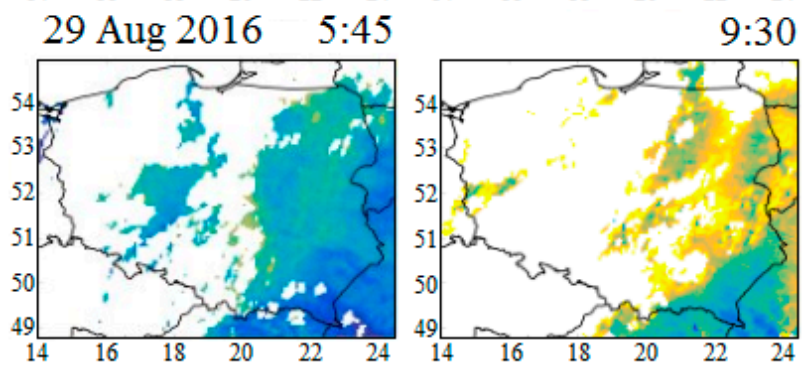

$9: 30$
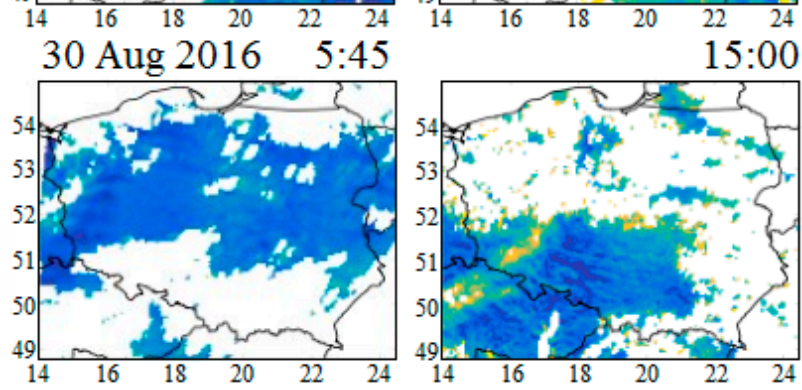

Figure 6. The SEVIRI AOD maps at $635 \mathrm{~nm}$ calculated for $15 \mathrm{~min}$ for early morning (5:45 UTC) and late afternoon (14:45 UTC) on 25-30 August 2016. The lack of maps on 26 August is due to the choice of this day being the reference day. On 29 and 30 August retrieval at 14:45 UTC was hindered; therefore, the closest-in-time maps are plotted. White pixels over land are due to clouds.

The SEVIRI AOD maps calculated on 25, 27-30 August 2016 are shown in Figure 6, where the morning maps obtained at 5:45 UTC (in the left column) and afternoon maps at 14:45 UTC (in the right column) are inter-compared. On 29 and 30 August retrieval at 14:45 UTC was hindered (due to high cloud coverage) and therefore the closest-in-time maps were plotted instead (i.e., 9:30 UTC and 15:00 UTC, respectively). Relatively high cloudiness is still evident on 29 and 30 August (white pixels over the land); on the other three days, the cloudiness was low. A striking feature in the AOD patterns 
is their persistent increase between the values observed in the morning with respect to the afternoon values. This is evident in all maps but it unlikely to be an artefact and should not be related to the zenith elevation angle nor (dependent on it) scattering angle, as retrieval in the more challenging autumn conditions of September 2016 did not reveal such behaviour [5]. It is speculated that on 29 August the clear increase of the AOD between 5:45 UTC and 9:30 UTC must have propagated towards even higher AOD values in the afternoon. For the cloudless 25-28 August in the morning, the AOD values are evenly spread over Poland, in the afternoon, slightly higher AODs are observed over eastern Poland. Interestingly, despite the cloud coverage on each consecutive day, beginning on 25 August until 29 August, there is a clear gradual increase of the AOD practically over the entire territory of Poland, regardless of whether in the mornings (increase from $<0.15$ to $<0.35$ ) or in the afternoons (increase from $<0.35$ to $<0.5$ ). On 30 August, AODs dropped to background values both in the morning $(<0.15)$ and afternoon $(<0.35)$.

The daily mean of the SEVIRI AOD maps at $635 \mathrm{~nm}$ (available on 25, 27-30 August), although slightly higher, still show generally-good agreement with the daily MODIS AOD at $550 \mathrm{~nm}$ available on 26-29 August (not shown for brevity).

Apart from the MODIS AOD product, the MODIS fire maps (available via NASA Worldview Website (https: / / worldview.earthdata.nasa.gov) were searched to allocate possible sources of active wild-fires that occurred before and during the analysed time period. Two composite maps are shown in Figure 7, where high surface-fire activity (red dots) over Portugal (left subfigure) on 23 August and over the north-west of Ukraine on 26 August 2016 (right subfigure) is indicated. According to the backward trajectories given in Figure 1, the air masses were likely to pick up the biomass burning aerosol from possible sources over Portugal and Ukraine, whereby along the pathway of the air masses no other possible fire activity could have played a role. There is also negligible indication of local fires over Poland and it is unlikely that it could have actively contributed to the measured aerosol properties.
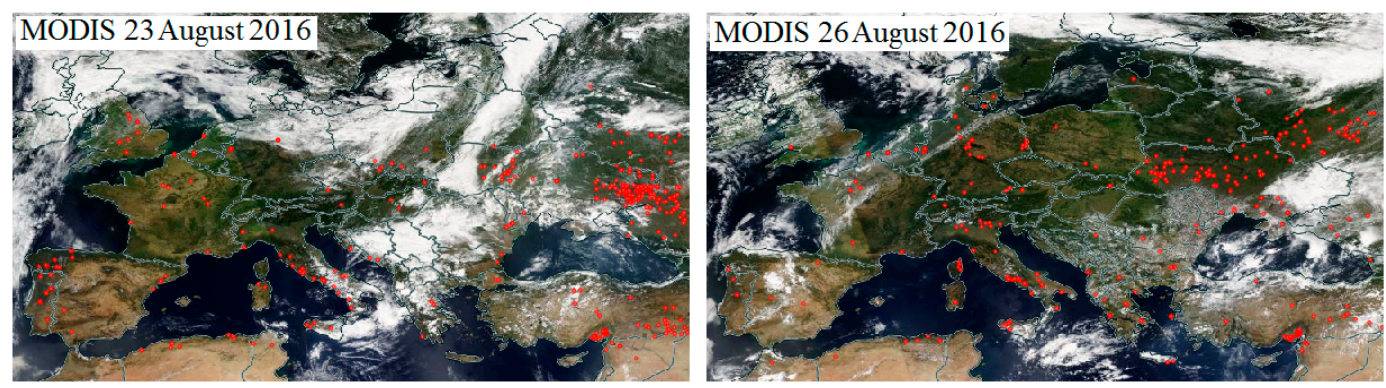

Figure 7. MODIS fire composites covering fire activity over Europe on 23 and 26 August, with the likely source of biomass burning over Portugal and Ukraine, respectively (source: EOSDIS Website at https:/ / worldview.earthdata.nasa.gov).

The ground-based passive remote sensing conducted within the PolandAOD network, agrees with the passive satellite SEVIRI and MODIS retrievals. The temporal evolution of the hourly mean values of AOD obtained at four PolandAOD sites for the period of 24 to 30 August 2016, is depicted in Figure 8. In Strzyzow, Rzecin and Raciborz AOD was detected with the CIMEL 318 photometer and in Warsaw with the MFR-7 radiometer. The cloud-screened AERONET product of Level 2.0 was available for Strzyzow and Raciborz, therefore the cloudiness over sites in Rzecin and Warsaw was assessed from radiation flux measurements (which in fact agree with the clouds measured by the lidar in Warsaw). During the analysed period, the observed AOD values were in general low, for most sites and days remaining below 0.15, with exception of the higher aerosol loads observed during 29 August. Unfortunately, on that day there is a significant number of missing data for many hours and sites, due to extensive cloud cover over most of the Poland territory (white pixels in Figure 6) with exception for Strzyzow site. However, it is unlikely that the AODs derived with radiometer 
and lidar over Warsaw, are contaminated by clouds, as the cloud screening was carefully performed. The clearest day in terms of cloud coverage and aerosol load was 26 August, with the hourly mean AODs below 0.1 at all sites (reference day for the SEVIRI AOD retrieval). The comparative analyses of the SEVIRI AOD, derived at pixels representative for the Warsaw, Rzecin, Raciborz and Strzyzow sites with the AOD data measured with CE318 photometers, MFR-7 radiometers and PollyXT lidar were revealing good agreement (correlation coefficients $\mathrm{r}^{2}$ of $0.91,0.84,0.8$ and 0.57 , respectively) as reported by [5]. Within the current study, lower correlation coefficients $(\sim 0.65)$ were obtained, which is mainly attributed to the generally lower AOD values.

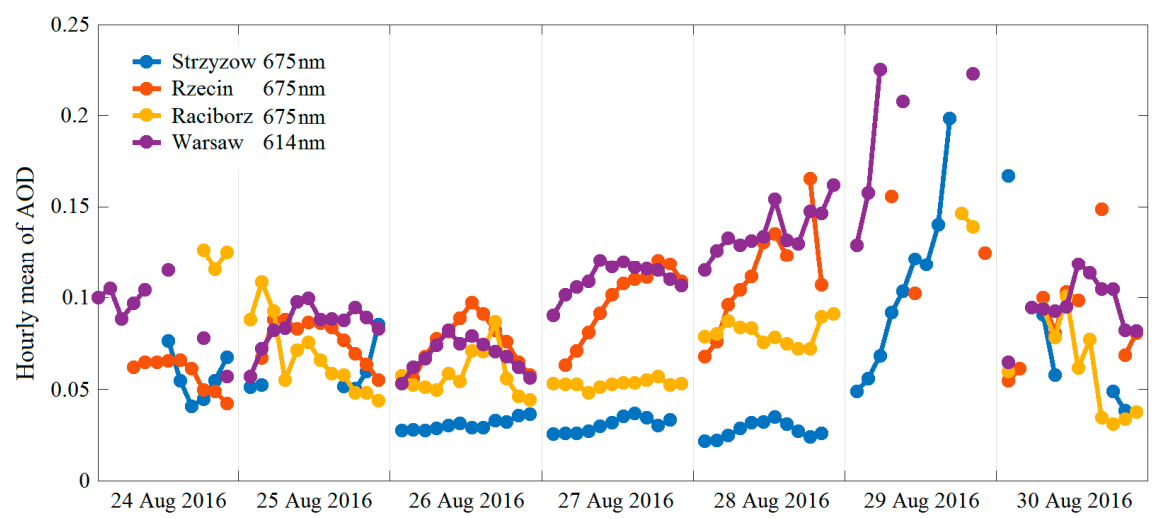

Figure 8. Hourly mean of AOD obtained at four locations of the PolandAOD network for period 24-30 August 2016. At AERONET stations in Rzecin (Level 1.5 data), Strzyzow and Raciborz (Level 2.0 data), AOD was measured by CIMEL photometer (source: https: / aeronet.gsfc.nasa.gov). At Warsaw site AOD was derived from MFR-7 radiometer measurements (source: www.polandaod.pl). The AOD measurement error of the CIMEL is \pm 0.01 and of the MFR-7 is \pm 0.025 .

During the course of events, the lowest AOD values were observed at the mountain site of Strzyzow in the south-east, especially on 26-28 August, characterized by an exceptionally low boundary layer depicted in Figure 2. The AODs in Strzyzow remained typical for this site, at values between 0.05-0.07 on 24-25 August. On 26-28 August AODs dropped even lower to a background value of $0.03 \pm 0.01$. On 29 August, within only $9 \mathrm{~h}$ they increased steeply up to 0.2 and fell back to typical values in the afternoon of 30 August. Somewhat similar behaviour but with roughly 2 times higher AODs and less sharp increase (from about 0.05 to 0.15 within 3 days) was observed at the semi-urban site of Raciborz in the south-west. In central Poland, at the urban site in Warsaw and the wetland site in Rzecin, the aerosol load enlarged persistently from below 0.1 up to 0.22 within 3 days and from below 0.07 to 0.16 within 5 days, respectively. Also at these two mid-country sites, on 30 August AOD decreased significantly to similar values as obtained before the event, on 24 August. Increase of the AODs on 29 August was due the frontal system passing over the country between the night of 28/29 August till the night of 29/30 August. The Ångström exponent (440/870) measured with the CIMEL instrument in Raciborz was rather stable 1.4-1.8 on 24-30 August but in Strzyzow it was strongly oscillating between 1.1 and 2.0. The Ångström exponent (415/870) measured with the MFR-7 radiometer in Strzyzow was alike (with slightly lower values). In Warsaw, the Ångström exponent (415/870) was between 0.4 and 1.6.

\section{Discussion and Interpretation}

\subsection{Model Results NAAPS and CAMS}

The results of the NAAPS model simulations (Navy Aerosol Analysis and Prediction System [69]; http: / / www.nrlmry.navy.mil/aerosol) over Poland on 24-30 August 2016 were used to interpret the results. For brevity, in Figure 9 simulations for 25, 27 and 29 August 2016 are shown, as indicating 
the general situation. The aerosol optical depth was predicted relatively low $<0.1$ for 24,25 and 26 August, increasing to $<0.2$ on 27 and 28 August, reaching maximum of 0.4 on 29 August. Note that the predicted AOD values compare reasonably to the AOD values derived from remote sensing measurements. A similar increasing trend for occurrence of sulphates $\left(<4 \mu \mathrm{g} \cdot \mathrm{m}^{-3}, 4-8 \mu \mathrm{g} \cdot \mathrm{m}^{-3}\right.$ and 4-16 $\mu \mathrm{g} \cdot \mathrm{m}^{-3}$, respectively) was predicted at the surface over central and southern Poland. Although on all days the surface smoke $\left(<2 \mu \mathrm{g} \cdot \mathrm{m}^{-3}\right)$ was slightly evident over only the south eastern tip of Poland (along the border with Ukraine); a significant smoke patch was sitting just outside the border on the grass/peatland fields of western Ukraine. Here again, the trend of gradually increasing concentrations and coverage was visible, whereby the maximum values on 29 August reached up to $256 \mu \mathrm{g} \cdot \mathrm{m}^{-3}$. On 30 August, the situation was back to background conditions, with aerosol optical depth below 0.1 , surface sulphates $<2 \mu \mathrm{g} \cdot \mathrm{m}^{-3}$ confined to south-western Poland and the smoke patch having shifted significantly over central Ukraine and Russia. For the entire period, no dust signatures over Europe were predicted.
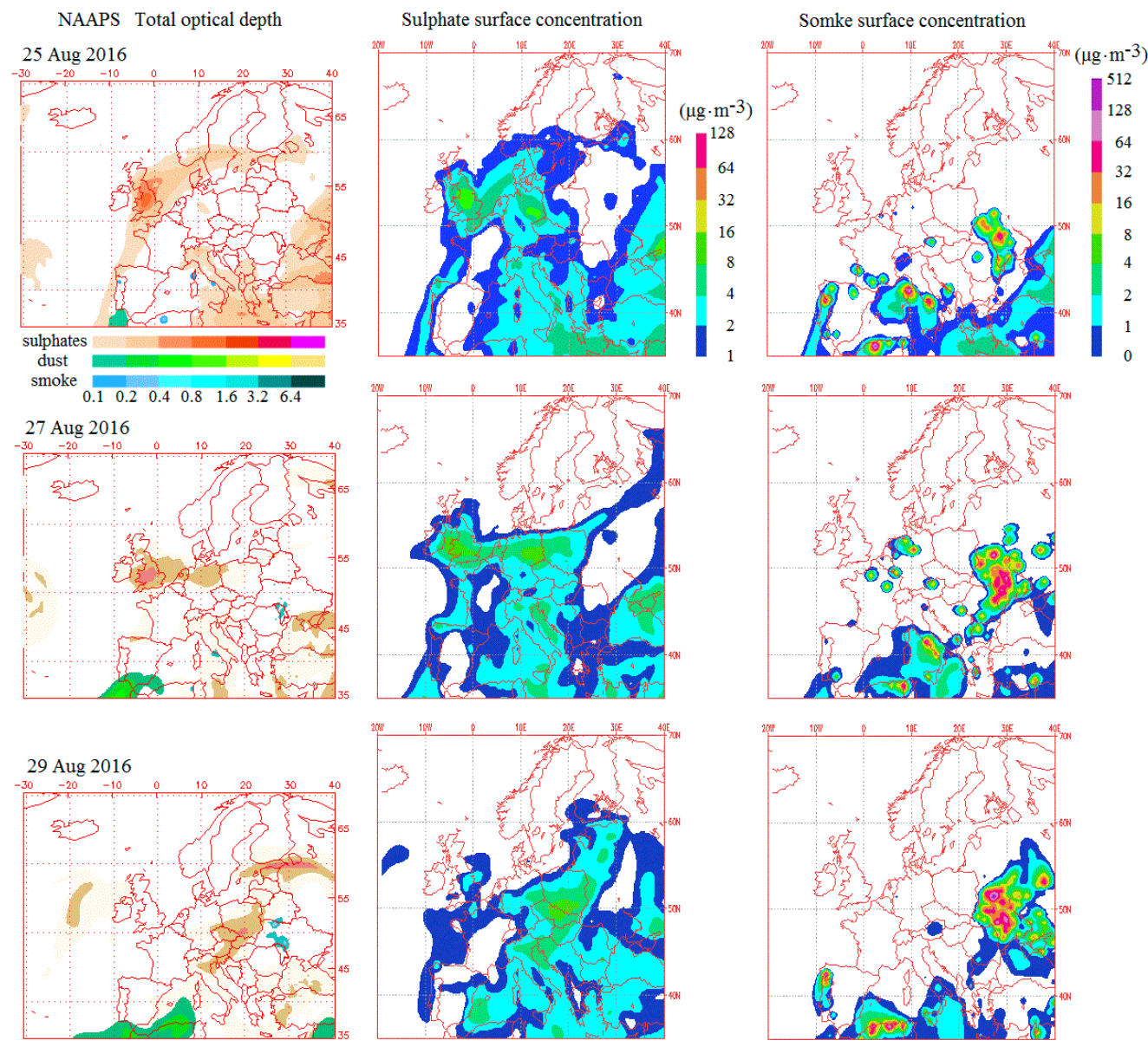

Figure 9. Navy Aerosol Analysis and Prediction System (NAAPS) aerosol optical depth (left) and concentration of surface sulphates (middle) and smoke (right) in $\mu \mathrm{g} \cdot \mathrm{m}^{-3}$ on 25,27 and 29 August 2016 (source: U.S. Naval Research Laboratory NRL/Monterey Aerosol Page http:/ / www.nrlmry.navy.mil/aerosol).

The results of the CAMS model (Copernicus Atmosphere Monitoring Service [56,57]; http:/ / atmosphere.copernicus.eu) indicated over Poland on 24-30 August 2016, the daily mean aerosol optical depths at $550 \mathrm{~nm}$ in the range of 0.05 to 0.35 . For the consecutive days, a clear AOD increase trend evident in the NAAPS simulations was less evident in the CAMS data. The AODs were rather evenly distributed over Poland on all days; still for 26-29 August, an increase of the AODs from roughly 0.1 
to 0.25 was captured. The highest AODs ranging from 0.3 to 0.35 were observed on 25 and 30 August and only over western Poland.

The AOD values over Warsaw are listed in Table 2, where the passive satellite remote sensors (5:45 UTC pixel of SEVIRI at $635 \mathrm{~nm}$ and daily mean pixel of MODIS at $500 \mathrm{~nm}$, both representative for the chosen location), the ground based passive remote sensor (the closest in time to 5:45 UTC columnar AOD derived by MFR-7 at $500 \mathrm{~nm}$ ), the active remote sensor (the closest in time to 5:45 UTC columnar AOD derived from PollyXT lidar signals at $532 \mathrm{~nm}$ ), as well as the AOD simulated by models (daily mean pixel of CAMS at $550 \mathrm{~nm}$ and NAAPS at $500 \mathrm{~nm}$ ) are in a good and expected general agreement. Data is listed with increasing AOD measurement wavelength to indicate the spectral differences between the obtained values. On each day, the differences in the obtained values are negligible within the given uncertainty ranges. The increase of the AOD on the following days of the event, was captured by all instruments and model outputs. On consecutive days, the NAAPS predicted AOD values in the range covering the observational values. The MODIS and SEVIRI derived AODs have slightly higher values that the lidar and radiometer derived AODs, which can be attributed to the different spatial representativeness of the data.

Table 2. Aerosol optical depth for 24-30 August 2016 for Warsaw reported by the model output (CAMS, NAAPS), derived at a satellite sensor pixel (SEVIRI, MODIS), as well as from lidar and radiometer measurements. Data is listed with an increasing wavelength.

\begin{tabular}{lcccccc}
\hline \multicolumn{7}{c}{ Aerosol Optical Depth } \\
\hline & NAAPS 500 & MODIS 500 & MFR-7 500 & LIDAR 532 & CAMS 550 & SEVIRI 653 \\
\hline 24 Aug 2016 & $<0.1$ & - & $0.1 \pm 0.025$ & - & $0.1 \pm 0.05$ & - \\
25 Aug 2016 & $<0.1$ & - & $0.09 \pm 0.025$ & $0.085 \pm 0.025$ & $0.12 \pm 0.05$ & $0.1 \pm 0.02$ \\
26 Aug 2016 & $<0.1$ & $0.08 \pm 0.06$ & $0.06 \pm 0.025$ & $0.06 \pm 0.03$ & $0.13 \pm 0.05$ & reference \\
27 Aug 2016 & $0.1-0.2$ & $0.12 \pm 0.07$ & $0.12 \pm 0.025$ & $0.11 \pm 0.03$ & $0.15 \pm 0.05$ & $0.15 \pm 0.03$ \\
28 Aug 2016 & $0.1-0.2$ & $0.2 \pm 0.08$ & $0.16 \pm 0.025$ & $0.16 \pm 0.04$ & $0.2 \pm 0.05$ & $0.2 \pm 0.03$ \\
29 Aug 2016 & $0.2-0.4$ & - & $0.22 \pm 0.025$ & $0.215 \pm 0.055$ & $0.2 \pm 0.05$ & $0.29 \pm 0.04$ \\
30 Aug 2016 & $<0.1$ & - & $0.09 \pm 0.025$ & $0.09 \pm 0.03$ & $0.1 \pm 0.05$ & $0.1 \pm 0.02$ \\
\hline
\end{tabular}

\subsection{Closure Data Interpretation against Surface PM Data}

As a final step of this work, the $\mathrm{PM}_{10}$ and $\mathrm{PM}_{2.5}$ data reported for the Warsaw-Ursynow WIOS monitoring site by the Warsaw Regional Inspectorate of Environmental Protection (available via http:/ /sojp.wios.warszawa.pl/raport-dobowy-i-roczny) was used to further interpret the results. Moderately polluted air $\left(10 \mu \mathrm{g} \cdot \mathrm{m}^{-3}<\mathrm{PM}_{2.5}<30 \mu \mathrm{g} \cdot \mathrm{m}^{-3}\right)$ was reported for 24-29 August and high air-quality $\left(\mathrm{PM}_{2.5}<10 \mu \mathrm{g} \cdot \mathrm{m}^{-3}\right)$ for 30 August.

The hourly mean values of surface $\mathrm{PM}_{10}$ and $\mathrm{PM}_{2.5}$ for the morning (6:00 UTC) and late afternoon (15:00 UTC) were compared to the columnar SEVIRI AOD, derived for Warsaw pixel at 5:45 UTC and 14:45 UTC, whereby on 24 August and in the afternoon of 29 August, no AOD retrieval was possible due to high cloud coverage over the location. For the results shown in Figure 10, all surface $\mathrm{PM}_{10}$ and $\mathrm{PM}_{2.5}$ (except on 30 August) were always lower in the afternoons (light blue and light red, respectively). Conversely, the SEVIRI AOD was always significantly higher in the afternoons (light grey). The morning $\mathrm{PM}_{10}$ and $\mathrm{PM}_{2.5}$ (dark blue/red pairs) were remarkably well correlated and followed the same increasing/decreasing tendency. For the afternoon $\mathrm{PM}_{10}$ and $\mathrm{PM}_{2.5}$ (light blue/red pairs) there was similar behaviour, although less pronounced. Note a clear difference between the morning and the afternoon tendencies of the observed PM changes, which seem neither proportional, nor correlated to each other (or vice versa). Based on the daily evolution of the hourly mean values of the $\mathrm{O}_{3}, \mathrm{NO}, \mathrm{NO}_{2}, \mathrm{NO}_{\mathrm{x}}, \mathrm{SO}_{2}$ and $\mathrm{C}_{6} \mathrm{H}_{6}$ measured at the Warsaw-Ursynow WIOS site (plots available via https: / / sojp.wios.warszawa.pl/dane-pomiarowe), an air pollution transport peak was not discernible, also a photo-smog occurrence was unlikely. Therefore, the observed differences were attributed to the morning inversion and the convective processes with efficient aerosol mixing in the planetary boundary layer in the afternoon. 
On the consecutive days, $\mathrm{PM}_{2.5}$ in the morning and in the afternoon, are anti-correlated, i.e., each increase/decrease in the morning was accompanied by a decease/increase in the afternoon. This was not observed for $\mathrm{PM}_{10}$, nor for SEVIRI AOD. The fine-to-coarse mass ratio (FCR), defined as the ratio of the $\mathrm{PM}_{2.5}$ to the difference between $\mathrm{PM}_{10}$ and $\mathrm{PM}_{2.5}$ [70], indicated significant domination of the fine particles (FCR values of $>1.5$ ) in the mornings. In the afternoon, the fine and coarse mode particles were distributed more-less equally (FCR 1), except for 30 August, when coarse particles clearly dominated (FCR for <0.5).

In comparison to the period of 24-28 August, on 29 August $\mathrm{PM}_{10}$ was significantly higher in the afternoon (being almost the same as its value in the morning). Note, the error in PM is of at least $5 \mu \mathrm{g} \cdot \mathrm{m}^{-3}$ and increases with increasing reading values. Moreover, on 30 August the $\mathrm{PM}_{10}$ in the afternoon was two times higher than in the morning. This could be attributed either to a possible pollen outbreak on 29-30 August (as showing similar behaviour as reported by [68]), and/or to the influence of the sea air mass, due to changing frontal weather situation.

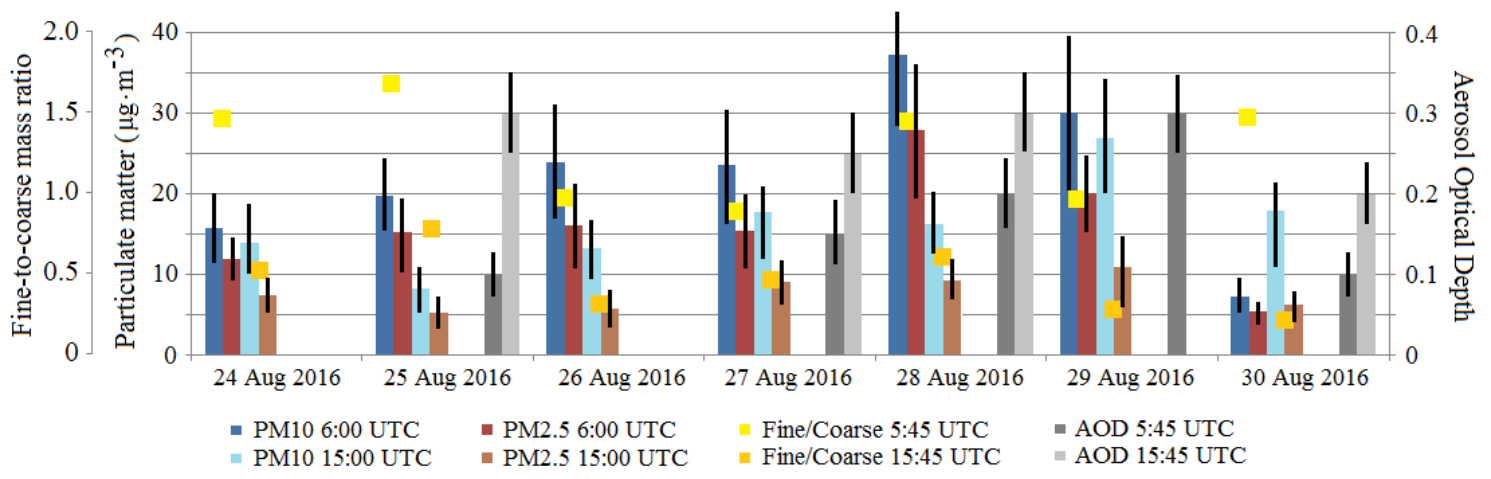

Figure 10. Hourly mean values of surface $\mathrm{PM}_{10}$ (blueish) and $\mathrm{PM}_{2.5}$ (reddish) at 6:00 UTC (darker) and 15:00 UTC (lighter) and fine-to-coarse PM mass ratio for the morning (in yellow) and for the afternoon (in orange) versus columnar SEVIRI AOD (greyish) for Warsaw pixel at 5:45 UTC (darker) and 14:45 UTC (lighter). On 24 and the afternoon of 29 August 2016, no AOD retrieval was possible due to high cloud coverage. There is also lack of AOD data for the reference day (26 August).

Daily mean values of surface $\mathrm{PM}_{10}$ and $\mathrm{PM}_{2.5}$ reported for the Warsaw-Ursynow WIOS monitoring site during 24-30 August 2016, were compared with the mean daytime SEVIRI columnar AOD at $635 \mathrm{~nm}$ derived for the Warsaw pixel, the mean daytime lidar-derived boundary layer AOD at $532 \mathrm{~nm}$ and the lidar-derived daytime boundary layer top. The results summarizing the comparisons are shown in Figure 11. The daily mean surface $\mathrm{PM}_{10}$ and $\mathrm{PM}_{2.5}$, columnar AOD and boundary layer AOD were increasing with increasing boundary layer height, to abruptly decrease on 30 August. The results indicated a good qualitative correspondence between the range-corrected, attenuated backscattering lidar signals (Figure 2) and the surface morning $\mathrm{PM}_{2.5}$ concentration; however, the lidar signal intensity increased in altitude-range but not in intensity-value, with the increasing $\mathrm{PM}_{2.5}$ concentration. Moreover, the daily mean surface $\mathrm{PM}_{2.5}$ data was correlated with the Ångström exponent (355/532) obtained from the lidar extinction profiles, whereby the daily $\mathrm{PM}_{2.5}$ high $\left(<10 \mu \mathrm{g} \cdot \mathrm{m}^{-3}\right)$ and moderate (10-15 $\left.\mu \mathrm{g} \cdot \mathrm{m}^{-3}\right)$ air-quality conditions reported during the analysed time period, revealed respectively moderate (0.8-1) and high (1.6-1.9) values of Ångström exponent (Figure 5). The measurements of daily mean $\mathrm{O}_{3}$ at the Warsaw-Ursynow WIOS site, indicated similar increase trend as both PM mean values, reaching the highest value of $72.6 \mu \mathrm{g} \cdot \mathrm{m}^{-3}$, regarded as moderately increased. As for the daily mean values of the $\mathrm{NO}_{2}, \mathrm{SO}_{2}$ and $\mathrm{C}_{6} \mathrm{H}_{6}$ measurements at the Warsaw-Ursynow WIOS site, no similarities were discernible with the $\mathrm{PM}_{10}, \mathrm{PM}_{2.5}$ and $\mathrm{O}_{3}$ trend. 


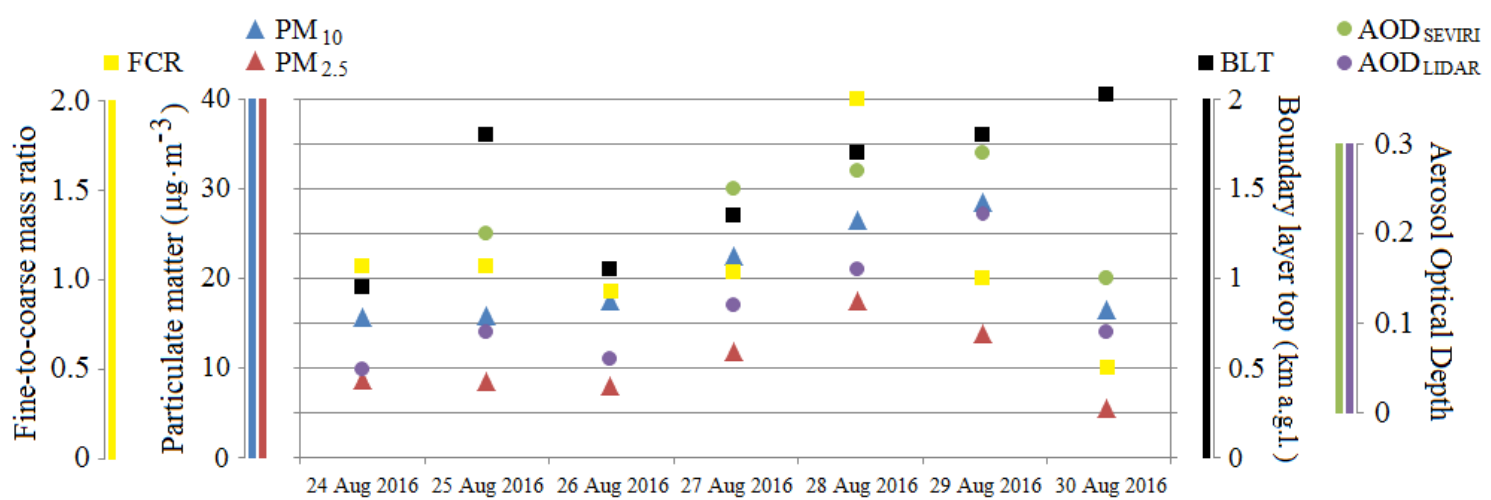

Figure 11. Daily mean values of surface $\mathrm{PM}_{10}$ (blue triangle) and $\mathrm{PM}_{2.5}$ (red triangle) at the WIOS Warsaw-Ursynow site during 24-30 August 2016 versus mean daytime SEVIRI columnar AOD at $635 \mathrm{~nm}$ for Warsaw pixel (green dot) and mean daytime lidar boundary layer AOD at $532 \mathrm{~nm}$ (violet dot), as compared to the lidar-derived daytime boundary layer top (black square). The fine-to-coarse mass ration is indicated in yellow. The data uncertainties are not plotted for the figure's clarity, they remain within $\mathrm{AOD}_{\mathrm{SEVIRI}} \pm 20 \%, \mathrm{AOD}_{\text {lidar }}(\mathrm{BL}) \pm 20 \%, \mathrm{BLT}_{\text {lidar }}<5 \%, \mathrm{PM}_{10}$ and $\mathrm{PM}_{2.5}<30 \%$.

For stationary high-pressure system and related heat wave conditions, an untypical boundary layer over the urban Warsaw site with an exceptionally high boundary layer top (BLT up to $3.2 \mathrm{~km}$ ) and related the increase of boundary layer top with AOD and surface $\mathrm{PM}_{2.5}$ increase but a decrease of AE532/355 was reported by [5]. They reported, for the air over Warsaw being a mixture of local and long-range transported anthropogenic pollution, that an increasing concentration of particles, of a size below $2.5 \mu \mathrm{m}$, was likely dominated by the fraction of coarse-mode particles (low AE). An injection of advected pollution (sulphates) from industrial regions of Germany into a locally polluted urban Warsaw's atmosphere, seems to have enhanced the heat wave conditions-an increase of both particle size and their concentration contributed to an exceptional increase of the heat wave driven boundary layer height top.

In the current work, the results differ in some respects. The boundary layer under a stationary anticyclone was dominated by a mixture of local pollution and long-range transported biomass burning aerosol. The boundary layer top was not as elevated (BLT $\sim 1-2 \mathrm{~km}$ ), there was still an increase of BLT in accordance with an increase of $\mathrm{AOD}$ and surface $\mathrm{PM}_{2.5}$ (as in the previous case); however, there was no decrease but increase of AE. Hence in this case, increasing concentration of particles of a size below $2.5 \mu \mathrm{m}$ resulted in a likely increase of the fraction of fine-mode particles (high AE). An injection of relatively fresh (1-2 day-old) and likely absorbing (locally heating), water insoluble biomass-burning aerosol from grass and peatland fires over Ukraine into locally polluted urban Warsaw's atmosphere seemed to moderate the weather conditions and likely counteracted possible heat wave development. Increased concentration of small-size and likely absorbing particles impaired the increase of the boundary layer height. The results discussed within this paper, as well as those reported by [5], were obtained under exceptionally dry conditions ( $\mathrm{RH}$ below 40\%), humidity and hygroscopic growth played a minor, if not negligible role.

\section{Conclusions}

Conducting this study, the 24/7 observations of PollyXT lidar collected during 24-30 August 2016 over Warsaw were used. The so-called $3 \beta+2 \alpha+2 \delta+w v$ datasets of day-time and night-time aerosol optical properties were obtained by using the lidar signals combined in the near and far-range. Air mass transport model HYSPLIT was used to discern air mass transport pathways. In general, in lower and middle troposphere, the air was circulating along the high-pressure system moving very slowly eastward. Different origin air masses were arriving at Warsaw in the boundary layer (relatively slow transport from Scandinavia over Eastern Europe) and the free troposphere (fast transport from 
the Iberian Peninsula over North-Eastern Europe). The boundary layer top, as related to the aerosol abundance in the lower troposphere, was derived by using the wavelet covariance applied on the lidar signals. The results of observations and calculations obtained for the period of interest were discussed with regard to optical properties simulated by models and measured by various remote sensors.

Lidar derived particle properties, characteristic for the boundary layer and for the aerosols that were suspended in the free troposphere above Warsaw, were calculated for the time period of 25-28 August 2016 and analysed in detail. The optical properties derived within the detected layers showed values which could be attributed to aerosols of a different origin: the moderately-fresh biomass burning particles from grass/peatland fires in Ukraine, the aged biomass burning particles from forest fires in Portugal, a local anthropogenic pollution and possibly a pollen.

In the free troposphere, the layers of the low in abundance, aged, 3-5 day-old forest fire biomass burning aerosol from Portugal, with $\mathrm{AE}(355 / 532)<1, \mathrm{LR}_{355}(<50 \mathrm{sr})<\mathrm{LR}_{532}(>70 \mathrm{sr}), \mathrm{DR}<2 \%$, as well as the layer with likely mixture of the aged, 3-4 day-old Portuguese biomass burning with the moderately-fresh, $<1$ day-old peatland fire biomass burning form Ukraine, with AE(355/532) of 1.5 and $\mathrm{LR}_{355}(\sim 40 \mathrm{sr})<\mathrm{LR}_{532}(\sim 50 \mathrm{sr}), \mathrm{DR}<1 \%$, were derived.

In the layers defined within the boundary layer, the background urban pollution aerosols were affected with an intruding Ukrainian biomass burning, being at first moderately-fresh $<1$ day old, then 1-2 day old, whereby the observed properties indicated AE(355/532) of 1-1.5 and LR 355 (55-70 sr) > LR 532 (50-62 sr) and at the end the intruding 1-2 day-old Ukrainian was mixed with the aged 3-4 day-old Portuguese biomass burning, whereby AE(355/532) of 1.3 and $\mathrm{LR}_{355}(\sim 80 \mathrm{sr})<\mathrm{LR} 532$ ( $\sim 85$ sr) was derived.

Lidar observations captured an increase of the boundary layer over Warsaw with likely accumulation of the biomass burning particles. An increase of the boundary layer top was not only related to an obvious increase of the surface temperature but also to the columnar aerosol optical depth and the surface $\mathrm{PM}_{10}$ and $\mathrm{PM}_{2.5}$, regardless of moderate $\left(10-30 \mu \mathrm{g} \cdot \mathrm{m}^{-3}\right)$ or high air-quality $\left(<10 \mu \mathrm{g} \cdot \mathrm{m}^{-3}\right)$. The daily mean surface $\mathrm{PM}_{2.5}$ data showed an increase with increasing lidar-derived Ångström exponent (AE532/355), whereby moderate air-quality conditions observed during the event revealed moderate and large values of AE532/355. It is likely, that the increase of the surface temperature was weakened by the likely absorbing, moderately-fresh biomass burning aerosols that were injected and accumulated below the boundary later top. Such mechanism might have contributed to diminishing the boundary layer top increase.

Acknowledgments: We acknowledge Alison Smuts-Simons for the Scientific-English proof reading of this paper. This work has been done as a joint effort within the frame of the Technical assistance for POlish radar and LIdar Mobile Observation System (POLIMOS) funded by ESA-ESTEC Contract No. 4000119961/16/NL/FF/mg and the SAtellite based Monitoring Initiative for Regional Air quality (SAMIRA) funded by the ESA-ESRIN Contract No. 4000117393/16/I-NB. The PollyXT Lidar was developed in a scientific collaboration of University of Warsaw and Leibniz Institute of Tropospheric Research. The lidar development was financed by the Polish Foundation of Science and Technology (FNTP-No. 519/FNITP/115/2010) and the Polish National Science Centre (NCN-2012/05/E/ST10/01578). The authors acknowledge the Polish Aerosol Research Network PolandAOD (http:/ / www.polandaod.pl) and the Warsaw Regional Inspectorate of Environmental Protection WIOS-Warsaw (http://www.wios.warszawa.pl) for the use of the networks data. We acknowledge Brent Holben, Alasdair MacArthur, Bogdan H. Chojnicki, Aleksander Pietruczuk, Michał Posyniak and Krzysztof K. Markowicz, for the use of the data from the Aerosol Robotic Network AERONET sites in Rzecin, Raciborz and Strzyzow, (https:/ /aeronet.gsfc.nasa.gov). The ceilometer observations at the Polish Academy of Sciences Observatory in Raciborz (http:/ / atmo.igf.edu.pl/Nimbus_Raciborz.php) were supported by the Polish National Science Centre (NCN-2013/09/ B/ST10/03553). The authors acknowledge the Institute of Meteorology and Water Management-The National Research Institute in Poland IMGW-PIB for the use of the weather charts. The HYSPLIT model was used via the Real-time Environmental Applications and Display System (READY) Website (http:/ / ready.arl.noaa.gov) of the NOAA Air Resources Laboratory. The NAAPS model output was used via the NRL/Monterey Aerosol Page (https:/ / www.nrlmry.navy.mil/aerosol), the contents of which contain products generated from models under development by researchers at the Marine Meteorology Division of the Naval Research Laboratory (NRL). This paper contains modified Copernicus Atmosphere Monitoring Service (CAMS) Information (2017); neither the EC nor the ECMWF is responsible for any use that may be made of the information it contains. The EARLINET is currently supported by the ACTRIS-2 project, funded by the European Union Research Infrastructure Action under the H2020 specific program for Integrating and opening existing national and regional research infrastructures of European interest under Grant Agreement No. 654109 (2015e2019). 
The University of Warsaw participates in ACTRIS-2 project as an associate partner without funding. Emmanouil Proestakis acknowledges support through the Stavros Niarchos Foundation. Nikolaos Siomos acknowledges the financial support of the State Scholarships Foundation (IKY) through the action "Scholarships programme for postgraduates studies-2nd Study Cycle".

Author Contributions: Iwona S. Stachlewska initiated the paper's concept, designed the study approach and solely wrote the paper; contributed to PollyXT lidar design, development and measurements, derived and analysed aerosol properties from lidar data, cross-compared and combined all data products and model outputs, described and interpreted the results, as well as concluded on relations between aerosol properties and the boundary layer characteristic. Mateusz Samson, Kamila M. Harenda, Patryk Poczta, Dominika Szczepanik and Iwona S. Stachlewska evaluated profiles of the aerosol optical properties from the lidar data. Nikolaos Siomos and Dominika Szczepanik calculated seasonal mean extinction profiles, based on the Warsaw site data in the EARLINET Data Base. Olga Zawadzka performed the retrieval of SEVIRI AOD maps over Poland and plotted ground based AODs. Lucja Janicka and Kamila M. Harenda performed the backward trajectory calculations. Lucja Janicka and Patryk Poczta performed synoptic analyses and heat index calculations. Kamila M. Harenda and Kerstin Stebel gathered the NAAPS and CAMS model output data. Iwona S. Stachlewska and Dongxiang Wang performed the retrieval of boundary layer heights. Karolina Borek and Anca Nemuc contributed with choice of relevant $\mathrm{PM}_{10}$ and $\mathrm{PM}_{2.5}$ data, based on WIOS Data Base. Eleni Tetoni and Emmanouil Proestakis contributed with suitable choice of CATS overpasses and data products for Warsaw location. Artur Szkop contributed with the ceilometer measurements in Raciborz. Bogdan H. Chojnicki, Krzysztof M. Markowicz and Aleksander Pietruczuk contributed with ground-based passive measurements and data quality assurance within Poland AOD network. Birgit Heese and Dietrich Althausen contributed with numerous hardware and software developments of the PollyXT lidar. Dirk Schuettemeyer and Claus Zehner contributed to this research in the frame of POLIMOS and SAMIRA projects. All authors performed the merit revision of this manuscript.

Conflicts of Interest: Authors declare no conflict of interest.

\section{References}

1. Pappalardo, G.; Amodeo, A.; Apituley, A.; Comeron, A.; Freudenthaler, V.; Linné, H.; Ansmann, A.; Bösenberg, J.; D'Amico, G.; Mattis, I.; et al. EARLINET towards an advanced sustainable European aerosol lidar network. Atmos. Meas. Tech. 2014, 7, 2389-2409. [CrossRef]

2. Holben, B.N.; Eck, T.F.; Slutsker, I.; Tanré, D.; Buis, J.P.; Setzer, A.; Vermote, E.; Reagan, J.A.; Kaufman, Y.J.; Nakajima, T.; et al. AERONET-A federated instrument network and data archive for aerosol characterization. Remote Sens. Environ. 1998, 66, 1-16. [CrossRef]

3. Lyamani, H.; Olmo, F.J.; Alcántara, A.; Alados-Arboledas, L. Atmospheric aerosols during the 2003 heat wave in southeastern Spain I: Spectral optical depth. Atmos. Environ. 2006, 40, 6453-6464. [CrossRef]

4. Chazette, P.; Totems, J.; Shang, X. Atmospheric aerosol variability above the Paris Area during the 2015 heat wave-Comparison with the 2003 and 2006 heat waves. Atmos. Environ. 2017, 170, 216-233. [CrossRef]

5. Stachlewska, I.S.; Zawadzka, O.; Engelmann, R. Effect of Heat Wave Conditions on Aerosol Optical Properties Derived from Satellite and Ground-Based Remote Sensing over Poland. Remote Sens. 2017, 9, 1199. [CrossRef]

6. Baars, H.; Kanitz, T.; Engelmann, R.; Althausen, D.; Heese, B.; Komppula, M.; Preißler, J.; Tesche, M.; Ansmann, A.; Wandinger, U.; et al. An overview of the first decade of PollyNET: An emerging network of automated Raman-polarization lidars for continuous aerosol profiling. Atmos. Chem. Phys. 2016, 16, 5111-5137. [CrossRef]

7. Ortiz-Amezcua, P.; Guerrero-Rascado, L.L.; Granados-Muñoz, M.J.; Benavent-Oltra, J.A.; Böckmann, C.; Samaras, S.; Stachlewska, I.S.; Janicka, L.; Baars, H.; Bohlmann, S.; et al. Microphysical characterization of long-range transported biomass burning particles from North America at three EARLINET stations. Atmos. Chem. Phys. 2017, 17, 5931-5946. [CrossRef]

8. Levy, R.C.; Remer, L.A.; Kleidman, R.G.; Mattoo, S.; Ichoku, C.; Kahn, R.; Eck, T.F. Global evaluation of the collection 5 MODIS dark-target aerosol products over land. Atmos. Chem. Phys. 2010, 10, 10399-10420. [CrossRef]

9. Zawadzka, O.; Markowicz, K.M. Retrieval of aerosol optical depth from optimal interpolation approach applied to SEVIRI data. Remote Sens. 2014, 6, 7182-7211. [CrossRef]

10. Fuchs, J.; Cermak, J. Where Aerosols Become Clouds-Potential for Global Analysis Based on CALIPSO Data. Remote Sens. 2015, 7, 4178-4190. [CrossRef]

11. Zhang, Q.; Ma, X.; Tie, X.; Huang, M.; Zhao, C. Vertical distributions of aerosols under different weather conditions: Analysis of in situ aircraft measurements in Beijing, China. Atmos. Environ. 2009, 43, 5526-5535. [CrossRef] 
12. Dörnbrack, A.; Stachlewska, I.S.; Ritter, C.; Neuber, R. Aerosol distribution around Svalbard during intense easterly winds. Atmos. Chem. Phys. 2010, 10, 1473-1490. [CrossRef]

13. Nicolae, D.; Nemuc, A.; Müller, D.; Talianu, C.; Vasilescu, J.; Belegante, L.; Kolgotin, A. Characterization of fresh and aged biomass burning events using multiwavelength Raman lidar and mass spectrometry. J. Geophys. Res. Atmos. 2013, 118, 2956-2965. [CrossRef]

14. Collaud, C.M.; Weingartner, E.; Furger, M.; Nyeki, S.; Prévôt, A.S.H.; Steinbacher, M.; Baltensperger, U. Aerosol climatology and planetary boundary influence at the Jungfraujoch analyzed by synoptic weather types. Atmos. Chem. Phys. 2011, 11, 5931-5944. [CrossRef]

15. Quan, J.; Gao, Y.; Zhang, Q.; Tie, X.; Cao, J.; Han, S.; Meng, J.; Chen, P.; Zhao, D. Evolution of planetary boundary layer under different weather conditions and its impact on aerosol concentrations. Particuology 2013, 11, 34-40. [CrossRef]

16. Dieudonné, E.; Chazette, P.; Marnas, F.; Totems, J.; Shang, X. Raman Lidar Observations of Aerosol Optical Properties in 11 Cities from France to Siberia. Remote Sens. 2017, 9, 978. [CrossRef]

17. Wang, H.; Xue, M.; Zhang, X.Y.; Liu, H.L.; Zhou, C.H.; Tan, S.C.; Che, H.Z.; Chen, B.; Li, T. Mesoscale modeling study of the interactions between aerosols and PBL meteorology during a haze episode in Jing-Jin-Ji (China) and its nearby surrounding region-Part 1: Aerosol distributions and meteorological features. Atmos. Chem. Phys. 2015, 15, 3257-3275. [CrossRef]

18. Meehl, G.A.; Tebaldi, C. More intense, more frequent and longer lasting heat waves in the 21st century. Science 2004, 305, 994-997. [CrossRef] [PubMed]

19. Della-Marta, P.M.; Haylock, M.R.; Luterbacher, J.; Wanner, H. Doubled length of western European summer heat waves since 1880. J. Geophys. Res. 2007, 112. [CrossRef]

20. García-Herrera, R.; Díaz, J.; Trigo, R.M.; Luterbacher, J.; Fischer, E.M. A Review of the European Summer Heat Wave of 2003. Crit. Rev. Environ. Sci. Technol. 2010, 40, 267-306. [CrossRef]

21. Tomczyk, A.M.; Bednorz, E. Heat waves in Central Europe and their circulation conditions. Int. J. Climatol. 2016, 36, 770-782. [CrossRef]

22. Lyamani, H.; Olmo, F.J.; Alcántara, A.; Alados-Arboledas, L. Atmospheric aerosols during the 2003 heat wave in southeastern Spain II: Microphysical columnar properties and radiative forcing. Atmos. Environ. 2006, 40, 6465-6476. [CrossRef]

23. Wastl, C.; Schunka, C.; Lüpkea, M.; Cocca, G.; Conederac, M.; Valese, E.; Menzel, A. Large-scale weather types, forest fire danger and wildfire occurrence in the Alps. Agric. For. Meteorol. 2013, 168, 15-25. [CrossRef]

24. Veselovskii, I.; Whiteman, D.N.; Korenskiy, M.; Suvorina, A.; Kolgotin, A.; Lyapustin, A.; Wang, Y.; Chin, M.; Bian, H.; Kucsera, T.L.; et al. Characterization of forest tire smoke event near Washington, DC in summer 2013 with multi-wavelength lidar. Atmos. Chem. Phys. 2015, 15, 1647-1660. [CrossRef]

25. Janicka, L.; Stachlewska, I.S.; Veselovskii, I.; Baars, H. Temporal variations in optical and microphysical properties of mineral dust and biomass burning aerosol derived from daytime Raman Lidar observations over Warsaw, Poland. Atmos. Environ. 2017, 169, 162-174. [CrossRef]

26. Markowicz, K.M.; Chilinski, M.T.; Lisok, J.; Zawadzka, O.; Stachlewska, I.S.; Janicka, L.; Rozwadowska, A.; Makuch, P.; Pakszys, P.; Zielinski, T.; et al. Study of aerosol optical properties during long-range transport of biomass burning from Canada to Central Europe in July 2013. J. Aerosol Sci. 2016, 101, 156-173. [CrossRef]

27. Lisok, J.; Rozwadowska, A.; Pedersen, J.G.; Markowicz, K.M.; Ritter, C.; Kaminski, J.W.; Struzewska, J.; Mazzola, M.; Udisti, R.; Becagli, S.; et al. Impact of a Strong Biomass Burning Event on the Radiative Forcing in the Arctic. Atmos. Chem. Phys. Discuss. 2017. in review. [CrossRef]

28. Chojnicki, B.H.; Harenda, K.M.; Samson, M.; Juszczak, R.; Markowicz, K.M.; Stachlewska, I.S.; Kleniewska, M.; MacArthur, A. Impact of atmospheric optical properties on wetland productivity. Remote Sens. 2018. in preparation.

29. Jacob, D.J.; Winner, D.A. Effect of climate change on air quality. Atmos. Environ. 2009, 43, 51-63. [CrossRef]

30. Silva, S.J.; Arellano, A.F. Characterizing Regional-Scale Combustion Using Satellite Retrievals of CO, $\mathrm{NO}_{2}$ and $\mathrm{CO}_{2}$. Remote Sens. 2017, 9, 744. [CrossRef]

31. Katsouyanni, K.; Pantazopoulou, A.; Touloumi, G.; Tselepidaki, I.; Moustris, K.; Asimakopoulos, D.; Poulopoulou, G.; Trichopoulos, D. Evidence for Interaction between Air Pollution and High Temperature in the Causation of Excess Mortality. Arch. Environ. Health Int. J. 1993, 48, 235-242. [CrossRef] [PubMed]

32. Fisher, P.H.; Brunekreef, B.; Lebret, E. Air pollution related deaths during the 2003 heat wave in the Netherlands. Atmos. Environ. 2004, 38, 1083-1085. [CrossRef] 
33. Stone, B., Jr. Urban Heat and Air Pollution: An Emerging Role for Planners in the Climate Change Debate. J. Am. Plan. Assoc. 2005, 71, 13-25. [CrossRef]

34. Tan, J.; Zheng, Y.; Tang, X.; Guo, C.; Li, L.; Song, G.; Zhen, X.; Yuan, D.; Kalkstein, A.J.; Li, F.; et al. The urban heat island and its impact on heat waves and human health in Shanghai. Int. J. Biometeorol. 2010, 54, 75-84. [CrossRef] [PubMed]

35. Ou, Y.; Zhao, W.; Wang, J.; Zhao, W.; Zhang, B. Characteristics of Aerosol Types in Beijing and the Associations with Air Pollution from 2004 to 2015. Remote Sens. 2017, 9, 898. [CrossRef]

36. Ritter, C.; Neuber, R.; Schulz, A.; Markowicz, K.M.; Stachlewska, I.S.; Lisok, J.; Makuch, P.; Pakszys, P.; Markuszewski, P.; Rozwadowska, A.; et al. 2014 iAREA campaign on aerosol in Spitsbergen—Part 2: Optical properties from Raman-lidar and in-situ observations at Ny-Ålesund. Atmos. Environ. 2016, 164, 431-447. [CrossRef]

37. Maciszewska, A.E.; Markowicz, K.M.; Witek, M.L. A multiyear analysis of aerosol optical thickness over Europe and Central Poland using NAAPS model simulation. Acta Geophys. 2010, 58, 1147-1163. [CrossRef]

38. Marchese, F.; Sannazzaro, F.; Falconieri, A.; Filizzola, C.; Pergola, N.; Tramutoli, V. An Enhanced Satellite-Based Algorithm for Detecting and Tracking Dust Outbreaks by Means of SEVIRI Data. Remote Sens. 2017, 9, 537. [CrossRef]

39. Nemuc, A.; Stachlewska, I.S.; Vasilescu, J.; Górska, A.; Nicolae, D.; Talianu, C. Optical properties of long-range transported volcanic ash over Romania and Poland during Eyjafjallajökull eruption in 2010. Acta Geophys. 2014, 62, 350-366. [CrossRef]

40. Corradini, S.; Montopoli, M.; Guerrieri, L.; Ricci, M.; Scollo, S.; Merucci, L.; Marzano, F.S.; Pugnaghi, S.; Prestifilippo, M.; Ventress, L.J.; et al. A Multi-Sensor Approach for Volcanic Ash Cloud Retrieval and Eruption Characterization: The 23 November 2013 Etna Lava Fountain. Remote Sens. 2016, 8, 58. [CrossRef]

41. Merucci, L.; Zakšek, K.; Carboni, E.; Corradini, S. Stereoscopic Estimation of Volcanic Ash Cloud-Top Height from Two Geostationary Satellites. Remote Sens. 2016, 8, 206. [CrossRef]

42. Szkop, A.; Pietruczuk, A. Analysis of aerosol transport over southern Poland in August 2015 based on a synergy of remote sensing and backward trajectory techniques. J. Appl. Remote Sens. 2017, 11, 11. [CrossRef]

43. Chazette, P.; Totems, J. Mini N2-Raman Lidar Onboard Ultra-Light Aircraft for Aerosol Measurements: Demonstration and Extrapolation. Remote Sens. 2017, 9, 1226. [CrossRef]

44. Markowicz, K.M.; Ritter, C.; Lisok, J.; Makuch, P.; Stachlewska, I.S.; Cappelletti, D.; Mazzola, M.; Chilinski, M.T. Vertical variability of aerosol single-scattering albedo and equivalent black carbon concentration based on in-situ and remote sensing techniques during the iAREA campaigns in Ny-Ålesund. Atmos. Environ. 2017, 164, 431-447. [CrossRef]

45. Engelmann, R.; Kanitz, T.; Baars, H.; Heese, B.; Althausen, D.; Skupin, A.; Wandinger, U.; Komppula, M.; Stachlewska, I.S.; Amiridis, V.; et al. The automated multiwavelength Raman polarization and water vapour lidar PollyXT: The neXT generation. Atmos. Meas. Tech. 2016, 9, 1767-1784. [CrossRef]

46. Yorks, J.E.; McGill, M.J.; Scott, V.S.; Wake, S.W.; Kupchock, A.; Hlavka, D.L.; Hart, W.D.; Selmer, P.A. The Airborne Cloud-Aerosol Transport System: Overview and Description of the Instrument and Retrieval Algorithms. J. Atmos. Ocean. Technol. 2014, 31, 2482-2497. [CrossRef]

47. McGill, M.J.; Yorks, J.E.; Scott, V.S.; Kupchock, A.W.; Selmer, P.A. The Cloud Aerosol Transport System (CATS): A technology demonstration on the International Space Station. In Lidar Remote Sensing for Environmental Monitoring XV, Proceedings of the SPIE Optical Engineering + Applications, San Diego, CA, USA, 9-13 August 2015; SPIE: Bellingham WA, USA, 2015; Volume 9612. [CrossRef]

48. Harrison, L.; Michalsky, J.; Berndt, J. Automated multifilter rotating shadow-band radiometer: An instrument for optical depth and radiation measurements. Appl. Opt. 1994, 33, 5118-5125. [CrossRef] [PubMed]

49. Aminou, D.M. MSG's SEVIRI Instrument. ESA Bull. 2000, 111, 15-17.

50. Stachlewska, I.S.; Costa-Suros, M.; Althausen, D. Raman lidar water vapour profiling over Warsaw, Poland. Atmos. Res. 2017, 194, 258-267. [CrossRef]

51. Heese, B.; Flentje, H.; Althausen, D.; Ansmann, A.; Frey, S. Ceilometer lidar comparison: Backscattering coefficient retrieval and signal-to-noise ratio determination. Atmos. Meas. Tech. 2010, 3, 1763-1770. [CrossRef]

52. Baars, H.; Ansmann, A.; Engelmann, R.; Althausen, D. Continuous monitoring of the boundary-layer top 725 with lidar. Atmos. Chem. Phys. 2008, 8, 7281-7296. [CrossRef]

53. Sokół, P.; Stachlewska, I.S.; Ungureanu, I.; Stefan, S. Evaluation of the boundary layer morning transition using the CL-31 ceilometer signals. Acta Geophys. 2014, 62, 367-380. [CrossRef] 
54. Wang, D.; Stachlewska, I.S.; Song, X.; Heese, B. Annual, seasonal and diurnal variability of boundary layer evolution over an urban continental site based on 10 years of remote sensing observations in Warsaw. Remote Sens. 2018. in review.

55. Rodgers, C. Inverse Methods for Atmospheric Sounding: Theory and Practice; Series on Atmospheric, Oceanic and Planetary Physics; World Scientific: Singapore, 2000; Volume 2.

56. Benedetti, A.; Morcrette, J.-J.; Boucher, O.; Dethof, A.; Engelen, R.J.; Fischer, M.; Flentjes, H.; Huneeus, N.; Jones, L.; Kaiser, J.W.; et al. The GEMS-AER team. Aerosol analysis and forecast in the ECMWF Integrated Forecast System. Part II: Data assimilation. J. Geophys. Res. 2009, 114. [CrossRef]

57. Morcrette, J.J.; Boucher, O.; Jones, L.; Salmond, D.; Bechtold, P.; Beljaars, A.; Benedetti, A.; Bonet, A.; Kaiser, J.W.; Razinger, M.; et al. Aerosol analysis and forecast in the ECMWF Integrated Forecast System. Part I: Forward modeling. J. Geophys. Res. 2009, 114D. [CrossRef]

58. Draxler, R.R.; Rolph, G.D. HYSPLIT (HYbrid Single-Particle Lagrangian Integrated Trajectory); Model access via NOAA ARL READY Website; NOAA Air Resources Laboratory: Silver Spring, MD, USA, 2010. Available online: http:/ / ready.arl.noaa.gov / HYSPLIT.php (accessed on 31 December 2017).

59. Rolph, G.D. Real-Time Environmental Applications and Display System (READY) Website; NOAA Air Resources Laboratory: Silver Spring, MD, USA, 2016. Available online: http://ready.arl.noaa.gov (accessed on 31 December 2017).

60. Stachlewska, I.S.; Piadlowski, M.; Migacz, S.; Szkop, A.; Zielinska, A.J.; Swaczyna, P.L. Ceilometer observations of the boundary layer over Warsaw, Poland. Acta Geophys. 2012, 60, 1386-1412. [CrossRef]

61. Wu, S.; Song, X.; Liu, B. Fraunhofer Lidar Prototype in the Green Spectral Region for Atmospheric Boundary Layer Observations. Remote Sens. 2013, 5, 6079-6095. [CrossRef]

62. Porter, J.N.; Lienert, B.; Sharma, S.K. Using the horizontal and slant lidar calibration methods to obtain aerosol scattering coefficients from a coastal lidar in Hawaii. J. Atmos. Ocean. Technol. 2000, 17, 1445-1454. [CrossRef]

63. Stachlewska, I.S.; Neuber, R.; Lampert, A.; Ritter, C.; Wehrle, G. AMALi-The Airborne Mobile Aerosol Lidar for Arctic research. Atmos. Chem. Phys. 2010, 10, 2947-2963. [CrossRef]

64. Stachlewska, I.S.; Ritter, C. On retrieval of lidar extinction profiles using Two-Stream and Raman techniques. Atmos. Chem. Phys. 2010, 10, 2813-2824. [CrossRef]

65. Müller, D.; Ansmann, A.; Mattis, I.; Tesche, M.; Wandinger, U.; Althausen, D.; Pisani, G. Aerosol-type-dependent lidar ratios observed with Raman lidar. J. Geophys. Res. Atmos. 2007, 112, 2156-2202. [CrossRef]

66. Huneeus, N.; Basart, S.; Fiedler, S.; Morcrette, J.-J.; Benedetti, A.; Mulcahy, J.; Terradellas, E.; Pérez García-Pando, C.; Pejanovic, G.; Nickovic, S.; et al. Forecasting the northern African dust outbreak towards Europe in April 2011: A model intercomparison. Atmos. Chem. Phys. 2016, 16, 4967-4986. [CrossRef]

67. Basart, S.; Pérez, C.; Cuevas, E.; Baldasano, J.M.; Gobbi, G.P. Aerosol characterization in Northern Africa, Northeastern Atlantic, Mediterranean Basin and Middle East from direct-sun AERONET observations. Atmos. Chem. Phys. 2009, 9, 8265-8282. [CrossRef]

68. Sicard, M.; Izquierdo, R.; Alarcón, M.; Belmonte, J.; Comerón, A.; Baldasano, J.M. Near-surface and columnar measurements with a micro pulse lidar of atmospheric pollen in Barcelona, Spain. Atmos. Chem. Phys. 2016, 16, 6805-6821. [CrossRef]

69. Lynch, P.; Reid, J.S.; Westphal, D.L.; Zhang, J.; Hogan, T.F.; Hyer, E.J.; Curtis, C.A.; Hegg, D.A.; Shi, Y.; Campbell, J.R.; et al. An 11-year global gridded aerosol optical thickness reanalysis (v1.0) for atmospheric and climate sciences. Geosci. Model Dev. 2016, 9, 1489-1522. [CrossRef]

70. Zawadzka, O.; Markowicz, K.M.; Pietruczukb, A.; Zielinski, T.; Jaroslawski, J. Impact of urban pollution emitted in Warsaw on aerosol properties. Atmos. Environ. 2013, 69, 15-28. [CrossRef]

(C) 2018 by the authors. Licensee MDPI, Basel, Switzerland. This article is an open access article distributed under the terms and conditions of the Creative Commons Attribution (CC BY) license (http:// creativecommons.org/licenses/by/4.0/). 